

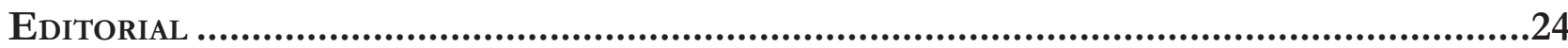

O Direito na fronteira da razão: Psicologia, neurociência e economia comportamental................... 24 Patrícia Perrone Campos Mello e Sergio Nojiri

I. NeURodireito: COGNIÇão, EMOÇÃo, JUÍZOS MORAIS E CIÊNCIA ..........................................26

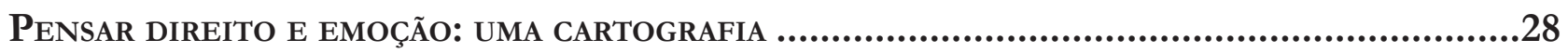

Nevita Maria Pessoa de Aquino Franca Luna

Neurodireito: o início, o fim E O MEIO

Carlos Marden e Leonardo Martins Wykrota

ENSAIO JURÍDICO SOBRE A RACIONALIDADE HUMANA: MAIORES, CAPAZES E IRRACIONAIS

André Perin Schmidt Neto e Eugênio Facchini Neto

DIVERGÊNCIAS DE PRINCÍPIO: ARGUMENTOS JURÍDICOS E MORAIS EM UM CENÁRIO DE DESACORDOS SOCIAIS

André Matos de Almeida Oliveira, Pâmela de Rezende Côrtes e Leonardo Martins Wykrota

CONSILIÊNCIA E A POSSIBILIDADE DO NEURODIREITO: DA DESCONFIANÇA À RECONCILIAÇÃO DISCIPLINAR.....

Thaís de Bessa Gontijo de Oliveira e Renato César Cardoso

MODELOS DE MORALIDADE

Molly J. Crockett

A INFELIZ BUSCA POR FELICIDADE No DiREITo

Úrsula Simões da Costa Cunha Vasconcellost, Noel Struchiner e Ivar Hannikainen

Além da liberdade: PersPeCtivas Em Nietzsche.

Lucas Costa de Oliveira

A mediaÇão de CONFlitos SOb a PERSPECTIVA do DESENVOLVIMENTO HUMANO: AS CONTRIBUIÇÕES DA PSICOLOGIA POSITIVA

Simone de Biazzi Ávila Batista da Silveira e Deise Brião Ferraz

Neuroimagiologia e aValiação de ResPonsabilidade

Nicole A. Vincent 
ANÁLISE CRÍTICA DA ORIENTAÇÃO DE CIDADÃOS COMO MÉTODO PARA OTIMIZAR DECISÕES PÚBLICAS POR MEIO DA TÉCNICA NUDGE.

Luciana Cristina Souza, Karen Tobias França Ramos e Sônia Carolina Romão Viana Perdigão

Políticas públicas e o deVer de monitoramento: “LEVANdo os Direitos A SÉrio". .252 Ana Paula de Barcellos

Nudges E POLÍticas PÚblicas: uM MECANISMO DE COMBATE AO TRABALHO EM CONDIÇÃo ANÁLOGA À DE ESCRAVO .267

Amanda Carolina Souza Silva, Débhora Renata Nunes Rodrigues e Saul Duarte Tibaldi

REDUZINDO A TRIBUTAÇÃO COGNITIVA: LIÇÕES COMPORTAMENTAIS PARA A DIMINUIÇÃO DOS EFEITOS PSICOLÓGICOS ADVERSOS DA POBREZA.............................................................288 Leandro Novais e Silva, Luiz Felipe Drummond Teixeira, Gabriel Salgueiro Soares e Otávio Augusto Andrade Santos

Políticas PÚBLICAS EM SUICÍDIO: DO PATERNALISMO CLÁSSICO AO PATERNALISMO LIBERTÁRIO E NUDGING

Davi de Paiva Costa Tangerino, Gabriel Cabral e Henrique Olive

Nudges COMO POLÍticA PÚbliCA PARA AUMENTAR O ESCASSO NÚMERO DE DOADORES DE ÓRGÃos PARA TRANSPLANTE

Roberta Marina Cioatto e Adriana de Alencar Gomes Pinheiro

Os PROGRAMAS DE INTEGRIDADE PARA CONTRATAÇÃO COM A ADMINISTRAÇÃO PÚBLICA ESTADUAL: NUDGE OU OBRIGAÇÃo LEGAL? UM OLHAR SOBRE AS DUAS PERSPECTIVAS .386

Cíntia Muniz Rebouças de Alencar Araripe e Raquel Cavalcanti Ramos Machado

Paternalismo libertário e Proteção JURídica do AMbiente: POR QUe PROTEger o AMBIENTE TAMBÉM DEVE SER PROTEGER AS LIBERDADES?

Mariana Carvalho Victor Coelho e Patryck de Araujo Ayala

Políticas PÚblicas baseadas EM EVIdÊNCIAS COMPORTAMENTAIS: REFLEXões A PARTIR do Projeto de Lei 488/2017 do Senado

Pâmela de Rezende Côrtes, André Matos de Almeida Oliveira e Fabiano Teodoro de Rezende Lara

III. ECONOMIA COMPORTAMENTAL: VIESES COGNITIVOS E POLÍTICAS PÚBLICAS .455

ECONOMIA COMPORTAMENTAL E DIREITO: A RACIONALIDADE EM MUDANÇA Marcia Carla Pereira Ribeiro e Victor Hugo Domingues

VIESES COGNITIVOS E DESENHO DE POLÍTICAS PÚBLICAS 
A neurociênCia da moralidade na tomada de DeCisões Jurídicas Complexas e No DESENHO DE POLÍTICAS PÚBLICAS

Erik Navarro Wolkart

Desvio de CARÁter ou SIMPLESMENTE HUMANO? ECONOMIA COMPORTAMENTAL APLICADA AO COMPORTAMENTO DESONESTO

Diana Orghian, Gabriel Cabral, André Pinto e Alessandra Fontana

Políticas Públicas e a ConcretizaÇão de direitos sociais: TOMAdA DE DECisão, ARQUITETURA DE ESCOLHAS E EFETIVIDADE

Ana Elizabeth Neirão Reymão e Ricardo dos Santos Caçapietra

BEHAVIORAL ECONOMICS E DIREITO DO CONSUMIDOR: NOVAS PERSPECTIVAS PARA O ENFRENTAMENTO DO SUPERENDIVIDAMENTO .568

Samir Alves Daura

A EDUCAÇÃo FORMAL PARA O CONSUMO É GARANTIA PARA UMA PRESENÇA REFLETIDA DO CONSUMIDOR NO MERCADO? UMA ANÁLISE COM BASE NA BEHAVIORAL LAW AND ECONOMICS (ECONOMIA COMPORTAMENTAL) 600

Marcia Carla Pereira Ribeiro e Edson Mitsuo Tiujo

LIBET, DETERMINISMO E CONSUMO: AS INFLUÊNCIAS DO MARKETING E A RELEVÂNCIA DA DELIBERAÇÃo CONSCIENTE NA SUPERAÇÃo CONDICIONAL DE HÁBITOS DE CONSUMO PERIGOSOS616 Émilien Vilas Boas Reis e Leonardo Cordeiro de Gusmão

CiÊNCIA DO DIREITO TRIBUTÁRIO, ECONOMIA COMPORTAMENTAL E EXTRAFISCALIDADE. .640 Hugo de Brito Machado Segundo

IV. CoMportamento JUdiCiAL: INFLUÊNCIA DE FATORES EXTRAJURÍDicos .660

FATORES METAPROCESSUAIS E SUAS INFLUÊNCIAS PARA A FORMAÇÃo DA DECISÃo JUDICIAL .662 Rogério Roberto Gonçalves de Abreu, Lúcio Grassi de Gouveia e Virgínia Colares

“A VIDA COMO ELA É": COMPORTAMENTO ESTRATÉGICO NAS CORTES Patrícia Perrone Campos Mello

A COMPOSIÇÃo do ÓRGão COLEGIAdo E SEUS EFEITOS NA TOMADA DE DECISÃo .720 André Garcia Leão Reis Valadares

Das 11 ilhas ao centro do arquipélago: os superpoderes do Presidente do STF DURANTE O RECESSO JUDICIAL E FÉRIAS .741 José Mário Wanderley Gomes Neto e Flávia Danielle Santiago Lima 
RAZÃo, EMOÇÃo E DELIBERAÇÃO: AS ADEQUAÇÕES REgIMENTAIS do SUPERIOR TribUNAL DE JUSTIÇA PARA A FORMAÇÃo DE PRECEDENTES EFICAZES

Peter Panutto e Lana Olivi Chaim

Heurística de ancoragem e fiXaÇÃo de danos morais em JUizados especiais Cíveis no Rio DE JANEIRO: UMA NOVA ANÁLISE 778

Fernando Leal e Leandro Molhano Ribeiro

LA PROTECCIÓN DE LOS DERECHOS POLÍTICOS FRENTE A LAS FUNCIONES DISCIPLINARIAS DE LAS AUTORIDADES ADMINISTRATIVAS: SUBSIDIARIEDAD Y DEFERENCIA EN EL SISTEMA INTERAMERICANO DE DERECHOS HUMANOS Jorge Ernesto Roa Roa

V. A influênCia do gÊNERo no PROCESSO DECisório JUdiCial

Como os Juízes decidem os Casos de estupro? ANALISANDo SENTENÇAS SOb A PERSPECTIVA DE VIESES E ESTEREÓTIPOS DE GÊNERO 826 Gabriela Perissinotto de Almeida e Sérgio Nojiri

GÊNERO E COMPORTAMENTO JUDICIAL NO SUPREMO TRIBUNAL FEDERAL: OS MINISTROS CONFIAM MENOS EM RELATORAS MULHERES?

Juliana Cesario Alvim Gomes, Rafaela Nogueira e Diego Werneck Arguelhes

Hércules, Hermes e a Pequena Sereia: uma reflexão sobre estereótipos de gênero, SUBPRESENTAÇÃo DAS MULHERES NOS TRIBUNAIS E (I)LEGITIMIDADE DEMOCRÁTICA DO PODER JUDICIÁRIO. .878 Jane Reis Gonçalves Pereira e Renan Medeiros de Oliveira

Prisão Cautelar de gestantes: análise do Fundamento filosófico da decisão do Habeas CoRpus N. 143.641 912

Artur César Souza e Giovania Tatibana de Souza

VI. Neurodireito APlicado ao direito E Ao Processo PENAL....................................926

CÉREbros QUe PUNEM: UMA REVISÃo CRÍTICA DA NEURoCIÊNCIA DA PUNIÇÃo .....................928 Ricardo de Lins e Horta

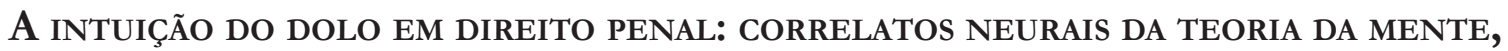
RACIOCÍNIO INDUTIVO E A GARANTIA DA CONVICÇÃO JUSTIFICADA. .946 Thiago Dias de Matos Diniz e Renato César Cardoso

As COMUNIDADES EPISTÊMICAS PENAIS E A PRODUÇÃo LEGISLATIVA EM MATÉRIA CRIMINAL..... 961 Stéphane Enguéléguélé 
DELINQUÊNCIA JUVENIL: RELAÇÕES ENTRE DESENVOLVIMENTO, FUNÇÕES EXECUTIVAS E COMPORTAMENTO SOCIAL NA ADOLESCÊNCIA .

André Vilela Komatsu, Rafaelle CS Costa e Marina Rezende Bazon

Límites TEMPORALES A LAS PENAS PRIVATIVAS DE LIBERTAD ATENDIENDO AL DESARROLLO PSICOSOCIAL.

Silvio Cuneo Nash

NEURolaw E AS PERSPECTIVAS PARA UMA ANÁLISE OBJETIVA DO COMPORTAMENTO SUGESTIONADO: REPERCUSSÃO DAS FALSAS MEMÓRIAS NA ESFERA PENAL

Mariana Dionísio de Andrade, Marina Andrade Cartaxo e Rafael Gonçalves Mota

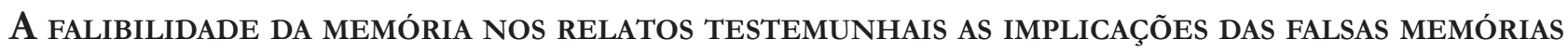
NO CONTEXTO DOS CRIMES CONTRA A DIGNIDADE SEXUAL

Caroline Navas Viana

A (IR)REPETIBILIDADE dA PROVA PENAL DEPENDENTE DA MEMÓRIA: UMA DisCUSSÃo COM BASE NA PSICOLOGIA DO TESTEMUNHO. 1058

William Weber Cecconello, Gustavo Noronha de Avila e Lilian Milnitsky Stein 


\section{Reduzindo a tributação cognitiva: lições comportamentais para a diminuição dos efeitos psicológicos adversos da pobreza*}

\author{
Reducing the cognitive taxes: behavioral \\ lessons to decrease the adverse psychological \\ effects from poverty
}

\author{
Leandro Novais e Silva** \\ Luiz Felipe Drummond Teixeira*** \\ Gabriel Salgueiro Soares**** \\ Otávio Augusto Andrade Santos*****
}

* Recebido em 31/05/2018 Aprovado em 10/08/2018

** Professor de Direito Econômico da FD/ UFMG. Doutor em Direito Econômico pela UFMG. Procurador do Banco Central do Brasil. Coordenador do Grupo de Estudos em Políticas Públicas da FD/UFMG. Email: leandro-novais@uol.com.br

*** Bacharelando em Direito pela UFMG. Membro dos Grupos de Estudo em Políticas Públicas e em Neuroética e Neurodireito da FD/UFMG. Email: luizfelipedrummond@ gmail.com

**** Bacharelando em Direito pela UFMG. Membro dos Grupos de Estudo em Políticas Públicas da FD/UFMG. Email: gsalgueiros@ gmail.com

***** Bacharelando em Direito pela UFMG. Membro dos Grupos de Estudo em Políticas Públicas e em Neuroética e Neurodireito da FD/UFMG. Email: al2012.121.andrade@ gmail.com

\section{Resumo}

A finalidade deste artigo é demonstrar que a pobreza impõe maiores custos cognitivos para a tomada de decisões. Utilizou-se o método de revisão bibliográfica, mediante a extensa análise de pesquisas empíricas das ciências comportamentais. Inicialmente, apresentam-se os pressupostos teóricos da Economia Comportamental, bem como a Teoria dos Prospectos, os Descontos Intertemporais Hiperbólicos e o Esgotamento do Ego. Posteriormente, discute-se como a pobreza potencializa vieses cognitivos, utilizando-se, como exemplo, uma maior aversão ao risco e maiores descontos intertemporais. Cria-se, então, uma verdadeira tributação cognitiva, visto que as decisões econômicas na pobreza são mais custosas cognitivamente. Contribuem para esse cenário, principalmente, um esgotamento do ego mais intenso, cumulado com a diminuição das funções cognitivas, maiores índices de stress e o foco atencional voltado para a escassez. Por fim, discute-se como as agendas de políticas públicas poderiam se pautar na utilização, sobretudo, de nudges como mecanismo de combate aos efeitos da tributação cognitiva. Para isso, serão analisados três exemplos de políticas públicas: duas que funcionam considerando aspectos comportamentais e o PRONATEC, que, por desconsiderá-los, tem conseguido menos êxito do que poderia. Conclui-se, em suma, que a pobreza - por si só - impõe severos custos cognitivos para o processo decisório. A agenda de políticas públicas poderia, nesse contexto, ser aprimorada por meio das teorias econômico-comportamentais, para facilitar a decisão em condição de pobreza. Finalmente, o trabalho destaca a importância dessa agenda de pesquisa, ressaltando a necessidade de dados para contribuições mais efetivas.

Palavras-chave: Esgotamento do Ego; Tributação Cognitiva; Pobreza; Empurrões; Políticas Públicas. 


\section{Abstract}

This paper aims to show that poverty imposes higher cognitive costs to decision-making. To prove this statement, we rely on an extensive review of behavioral science research, especially the experimental one. First of all, we present the theoretical grounds of Behavioral Economics, as well as the Prospects Theory, the Hyperbolic Intertemporal Discounts and the Ego Depletion. After that, we discuss how poverty increases cognitive biases, using, as an example, a greater risk aversion and bigger intertemporal discounts. It creates, therefore, a truly cognitive tax, as long as the decision-making in poverty is more cognitively expensive. Contribute to this situation factors that go mainly through an intensified ego depletion, cumulated with the impairment of cognitive functions, greater stress levels and the attentional focus facing the scarcity. Finally, we discuss how policy making agenda could mainly use nudges as a mechanism to reduce the cognitive taxes. To show that, it will be analyzed three examples of public policies: two that work well relying on behavioral insights and the PRONATEC, which are not having as much success as it could, because it ignore these insights. We conclude, to sum up, that poverty - by itself - imposes severe cognitive costs in decision-making process. In this context, the policy making agenda could be improved by using the behavioral economical theories, as a way to simplify the decision in a poverty condition. Finally, the paper highlights the importance of this research agenda, underlining that data is necessary to contribute in a more effective way to public policy.

Keywords: Ego Depletion; Cognitive Taxes; Poverty; Nudges; Public Policy.

\section{INTRODUÇÃo}

Sob o paradigma da Economia Comportamental, principalmente com base nos estudos de Daniel Kahneman e Amos Tversky, críticos do modelo neoclássico de tomada de decisões, duas formas distintas de pensar podem ser identificadas. A primeira, conhecida como Sistema 1, é intuitiva e impulsiva. Toma decisões rápidas e que exigem pouco esforço cognitivo. O outro modo de pensar é conhecido como Sistema 2 e é deliberativo, baseado na reflexão e com um maior custo cognitivo. Em muitas ocasiões, o processo decisório é guiado pelo Sistema 1, que exige menor esforço, mas que, também, apresenta erros frequentes e previsíveis.

O funcionamento do Sistema 2, por sua vez, demanda um suprimento de recursos psicologicamente escassos, que, quando esgotado, prejudica o rumo das decisões deliberadas. O comportamento passa a ser moldado, então, pelo Sistema 1, rápido, intuitivo e com baixo esforço. Esse processo foi demonstrado experimentalmente por vários autores, sobretudo Roy Baumeister, e ficou conhecido como Esgotamento do Ego (ego depletion). Dessa forma, quando submetidos a decisões complexas, cognitivamente custosas, os humanos esgotam mais rapidamente sua capacidade deliberativa, o que causa prejuízos relacionados ao autocontrole, às decisões reflexivas e, em geral, às escolhas econômicas, como aquelas relacionadas ao desconto intertemporal e à aversão ao risco.

Pessoas em situações de pobreza, submetidas a situações de maior escassez, precisam tomar decisões complexas de maneira mais cotidiana e com implicações mais significativas. Isso porque, a essas pessoas, trade-offs mais importantes se impõem e os custos de oportunidade de qualquer decisão são elevados. O esgotamento do ego, então, parece ser provocado de maneira mais intensa, o que faz com que as decisões econômicas tomadas por tais indivíduos, principalmente a longo prazo, apresentem uma tendência a ser prejudicadas pelo processo psicológico citado anteriormente. Outros fatores se adicionam a essa conjuntura e estão ligados a diminuições das funções cognitivas, stress, afeto negativo e um foco atencional direcionado para a própria situação de escassez. 
Por conta disso, Mani et al. ${ }^{1}$ sugerem que tais indivíduos são submetidos a uma maior tributação cognitiva, em face das pessoas que ocupam os estratos socioeconômicos superiores. Tal expressão - que não pretende significar a cobrança efetiva de tributos - visa a demonstrar, metaforicamente, que há custos cognitivos mais elevados inerentes às decisões feitas em situação de pobreza. Tal fato pode levar a decisões econômicas equivocadas, o que pode ser capaz de criar resultados extremamente regressivos a longo prazo. Estaria estabelecido, pois, um ciclo vicioso, na medida em que os pobres decidem sob maior pressão e com maiores custos de oportunidade e cognitivos, o que faz com que decidam economicamente de maneira insatisfatória com maior frequência. Conseguem, então, por exemplo, terem maiores descontos intertemporais ou se apresentarem mais avessos ao risco em situações em que a aceitação deste poderia levar a um resultado econômico mais satisfatório a longo prazo. A regressividade é, portanto, clara: decisões econômicas insatisfatórias levam a piores resultados econômicos, que, por sua vez, têm o condão de reforçar a situação de pobreza e, dessa forma, as escolhas econômicas futuras se tornam ainda mais difíceis.

Embora seja difícil a superação do ciclo vicioso narrado, pontua-se que essa situação pode ser atenuada com mudanças sutis na arquitetura de escolhas. Para isso, o artigo se baseia na larga revisão da literatura científico-comportamental, especialmente no que diz respeito aos experimentos relacionados ao esgotamento do ego, às más-decisões econômicas relacionadas a este fenômeno e à relação de todas essas condições com a pobreza.

Muitas vezes, inúmeras decisões complexas e ininteligíveis são exigidas dos cidadãos, ainda que eles não sejam capazes de decidir de maneira adequada nessas ocasiões, como, por exemplo, em relação aos planos de previdência ou ao mercado de créditos. O cenário desfavorável parece acelerar o processo de esgotamento do ego, especialmente pernicioso aos indivíduos em situação de pobreza, o que prejudica ainda mais as suas decisões econômicas. O resultado é uma menor taxa de poupança, gastos muitas vezes impulsivos e descontrolados e dívidas de tamanhos assustadores. Obviamente, políticas que atuem diretamente na redistribuição de renda serão impactantes, mas ultrapassam os objetivos deste trabalho. A solução que aqui é proposta passa pelo conceito de nudges, tal como proposto por Thaler e Sunstein. O arquiteto de escolhas, diante de tais circunstâncias, pode alterar a estrutura em que as pessoas tomam decisões, facilitando-as e direcionando-as para resultados que seriam melhores para os indivíduos, segundo as suas próprias concepções. Na formulação de qualquer política, dessa forma, deve-se ter em mente os vieses comportamentais exacerbados em condição de pobreza e esperar o erro, de forma a não o tornar excessivamente penoso.

Nesse contexto, o trabalho apresenta os prejuízos decisórios que a situação de pobreza pode trazer consigo e demonstra que eles podem ser atenuados com a formulação de políticas públicas adequadas. Seria possível, então, diminuir os efeitos psicologicamente adversos da pobreza e fazer com que as pessoas mais pobres pudessem decidir melhor, deliberando de forma mais precisa acerca de questões que lhes sejam mais urgentes. Na seção 2, serão apresentadas algumas lições preliminares baseadas nas ciências comportamentais. Brevemente, serão expostos os conceitos básicos ligados às decisões sob risco, consubstanciados na Teoria dos Prospectos, e aos descontos intertemporais e será feita uma revisão bibliográfica acerca do esgotamento do ego (ego depletion). Na seção 3, expostos tais conceitos comportamentais que se ligam de maneira mais direta ao objeto do trabalho, será demonstrado como a situação de pobreza impacta as decisões econômicas, sobretudo no que diz respeito à aversão ao risco e aos descontos intertemporais excessivos. As razões para tanto parecem girar em torno de um processo de esgotamento do ego intensificado, cumulado com fatores como a diminuição das funções cognitivas, um foco atencional voltado para a escassez e um aumento dos níveis de stress e de afeto negativo. Por fim, a seção 4 apresenta como isso impacta a formulação de políticas públicas, adotando a perspectiva dos nudges para reduzir os efeitos da tributação cognitiva. Serão expostas três políticas públicas diferentes: duas que obtiveram êxito ao considerar aspectos comportamentais e uma que falha ao não considerar tais aspectos. Esta última é o Programa Nacional de Acesso ao Ensino Técni-

1 MANI, A. et al. Poverty impedes cognitive function. Science, [s.1.], v. 341, n. 6149, p. 976-980, 29 ago. 2013. American Association for the Advancement of Science (AAAS). Disponível em: <http://dx.doi.org/10.1126/science.1238041>. p. 980. 
Co - PRONATEC, que, por não esperar o erro dos seus destinatários, apresenta notórios índices de evasão - que colocam em risco o próprio futuro desta política pública. Também serão demonstradas maneiras de se aprimorar tal programa, com o uso de estratégias comportamentais, principalmente na forma de nudges.

\section{A CRÍTICA DA ECONOMIA COMPORTAMENTAL: LIÇÕES PRELIMINARES}

Como ponto de partida, é necessário entender qual a razão de ser da Economia Comportamental. Com base nas diversas influências cognitivas, emocionais e sociais que moldam a tomada de decisão humana, tal corrente econômica elabora uma forte crítica ao modelo de comportamento econômico neoclássico, consubstanciado na figura do Homo Economicus.

Para Ariely², a Economia Neoclássica:

[...] presume que somos racionais - que conhecemos todas as informações pertinentes a nossas decisões, que podemos recalcular o valor das diversas opções com que nos deparamos e que estamos cognitivamente desobstruídos ao pesar as ramificações de cada escolha possível.

O resultado é que se pressupõe que tomamos decisões lógicas e sensatas e, mesmo que tomemos uma decisão errada de vez em quando, a perspectiva da economia tradicional indica que aprenderemos rapidamente com nossos erros, tanto por conta própria quanto com a ajuda das "forças do mercado". Com base nessas hipóteses, os economistas tiram conclusões de longo alcance acerca de qualquer coisa, de tendências em compras, passando pelo direito, a políticas públicas.

Os agentes econômicos, então, para o modelo tradicional da Economia, ponderam os custos e os benefícios de cada alternativa, adotando a conduta capaz de lhes proporcionar o maior bem-estar ${ }^{3}$. É o que se chama de conduta racional maximizadora. Na medida em que os agentes econômicos ponderam custos e benefícios ao decidir, uma mudança na matriz de incentivos altera, consequentemente, as suas condutas e os leva a realizarem outras escolhas ${ }^{4}$.

A Economia Comportamental nasce com um caráter suplementar ao modelo tradicional neoclássico, propondo uma nova abordagem no que diz respeito ao comportamento dos agentes econômicos. Thaler e Sunstein ${ }^{5}$, por exemplo, enfatizam que, apesar de destacarem inúmeros fatores negligenciados pela teoria econômica tradicional, não pretendem sugerir que as forças econômicas tradicionais não são importantes. Por isso, o caráter suplementar.

Tal vertente da Economia propõe, com base em robustas evidências empíricas, que, em vez de essencialmente racionais maximizadores, isto é, seres egoístas, que calculam o custo-benefício de suas ações e donos de preferências estáveis, os humanos, na maior parte das vezes, decidem de forma rápida e intuitiva ${ }^{6}$. Para isso, baseiam suas decisões em heurísticas, isto é, atalhos mentais utilizados para responder perguntas difíceis intuitivamente. Por exemplo, determinar a idade de uma celebridade ou a distância entre duas cidades? Esta forma de pensar, no entanto, leva configuração de vieses, quais sejam, erros sistemáticos e previsíveis.

2 ARIELY, Dan.Previsivelmente Irracional.Rio de Janeiro: Elsevier, 2008. p. 195.

3 GICO JÚNIOR, Ivo Teixeira. Metodologia e epistemologia da análise econômica do direito.Economic Analysis of Law Review, Brasília, v. 1, n. 1, p. 7-33, 11 jun. 2010. Semestral. p. 22.

4 GICO JÚNIOR, Ivo Teixeira. Metodologia e epistemologia da análise econômica do direito.Economic Analysis of Law Review, Brasília, v. 1, n. 1, p. 7-33, 11 jun. 2010. Semestral. p. 22.

5 THALER, Richard H.; SUNSTEIN, Cass R.Nudge:improving decisions about health, wealth and happiness. Londres: Penguin Books, 2009. p. 99.

6 SAMSON, Alain. Introdução à economia comportamental e experimental. In: ÁVILA, Flávia; BIANCHI, Ana Maria.Guia de Economia Comportamental e Experimental.São Paulo: Economiacomportamental.org, 2015. p. 25-59. p. 25.

7 THALER, Richard H.; SUNSTEIN, Cass R.Nudge:improving decisions about health, wealth and happiness. Londres: Penguin Books, 2009. p. 22-23. 
Diversos são as heurísticas e os vieses já mapeados pela Economia Comportamental ${ }^{8}$. Para o escopo deste trabalho, entretanto, foram selecionados apenas os desvios comportamentais que guardam relação mais direta com a temática tratada. Isso não retira a importância dos demais para a adequada compreensão do comportamento humano.

Preliminarmente, é necessário compreender como se operam as distintas formas de pensar que atuam na tomada de decisão do Homo Sapiens. Uma delas funciona de forma intuitiva, rápida e pouco onerosa cognitivamente; a outra, de forma lenta, deliberada e com um alto grau de esforço cognitivo?.

\subsection{Dois sistemas: rápido e devagar}

Em primeiro lugar, considere uma decisão tomada de maneira instantânea. Pense, por exemplo, em um caminhoneiro experiente que dirige pelas rodovias. Ou, mesmo, em um exímio jogador de tênis. Ambos decidem automaticamente. Em razão de suas habilidades, o motorista não delibera os custos e benefícios de cada ultrapassagem, da mesma forma que o jogador não calcula a trajetória da bola a cada saque.

Por outro lado, imagine um engenheiro realizando os cálculos aerodinâmicos de um avião. Ou, ainda, a realização de um exame para ingresso no Ensino Superior. Os dois casos envolvem deliberações e não parecem ser intuitivos. Há ponderações frequentes e o raciocínio é lento e analítico.

Os primeiros exemplos evocam uma forma de pensar instantânea. Por outro lado, os seguintes parecem exigir maior atenção, por se tratarem de problemas nitidamente mais complexos e que, portanto, demandam um pensamento mais deliberado e reflexivo. Para Kahneman ${ }^{10}$, a cognição humana opera conforme dois sistemas distintos, ora de forma rápida (Sistema 1), ora devagar (Sistema 2$)^{11}$.

O Sistema 1, como já foi ressaltado, é automático. Trabalha com pouco esforço e é involuntário. É associativo e habilidoso e não está envolvido com o que, normalmente, é associado ao pensar ${ }^{12}$. Já o Sistema 2 é mais lento. Atua nas atividades mentais trabalhosas, que envolvem maior esforço e concentração ${ }^{13}$. Suas operações são controladas voluntariamente, dedutivas, conscientes e seguem regras lógicas ${ }^{14}$.

É o Sistema 1, portanto, que atua na maior parte do tempo, colocando o Sistema 2 em um confortável modo de pouco esforço, com apenas uma fração de sua capacidade envolvida ${ }^{15}$. Em outros termos, a maior parte do que o sistema reflexivo faz e pensa é originada do sistema automático; para tarefas mais complexas, no entanto, o Sistema 2 assume o controle e, normalmente, tem a última palavra.

O pensamento guiado pelo Sistema 1 é, via de regra, eficiente. Todavia, conforme explica Kahneman ${ }^{16}$,

8 Para a melhor compreensão das heurísticas e vieses, as seguintes obras são sugeridas:

KAHNEMAN, Daniel.Rápido e devagar:duas formas de pensar. Rio de Janeiro: Objetiva, 2012.;

THALER, Richard.Misbehaving:the making of behavioral economics. Nova Iorque: W. W. Norton, 2016.

ARIELY, Dan.Previsivelmente Irracional.Rio de Janeiro: Elsevier, 2008.

ARIELY, Dan.Positivamente irracional:os benefícios inesperados de desafiar a lógica em todos os aspectos de nossas vidas. Rio de Janeiro: Elsevier, 2010.

ÁVILA, Flávia; BIANCHI, Ana Maria.Guia de economia comportamental e experimental.São Paulo: Economiacomportamental.org, 2015.

9 KAHNEMAN, Daniel.Rápido e devagar:duas formas de pensar. Rio de Janeiro: Objetiva, 2012. p. 30-33.

10 KAHNEMAN, Daniel.Rápido e devagar:duas formas de pensar. Rio de Janeiro: Objetiva, 2012. p. 29.

11 Vale ressaltar que o cérebro deve ser visto como uma uniformidade. Os dois sistemas, ainda que representem diversas formas de pensar, não são uma real divisão cerebral, isto é, não são morfologicamente identificáveis, ainda que a atividade cerebral possa ser mais intensa em uma ou outra área, conforme se decide de forma intuitiva ou deliberada.

12 THALER, Richard H.; SUNSTEIN, Cass R.Nudge:improving decisions about health, wealth and happiness. Londres: Penguin Books, 2009. p. 19-20.

13 KAHNEMAN, Daniel.Rápido e devagar:duas formas de pensar. Rio de Janeiro: Objetiva, 2012. p. 29.

14 THALER, Richard H.; SUNSTEIN, Cass R.Nudge.improving decisions about health, wealth and happiness. Londres: Penguin Books, 2009. p. 22-23.

15 KAHNEMAN, Daniel.Rápido e devagar:duas formas de pensar. Rio de Janeiro: Objetiva, 2012. p. 33.

16 KAHNEMAN, Daniel.Rápido e devagar:duas formas de pensar. Rio de Janeiro: Objetiva, 2012. p. 38. 
em situações específicas tal Sistema comete erros sistemáticos:

Como o Sistema 1 opera automaticamente e não pode ser desligado a seu bel-prazer, erros do pensamento intuitivo muitas vezes são difíceis de prevenir. Os vieses nem sempre podem ser evitados, pois o Sistema 2 talvez não ofereça pista alguma sobre o erro. Mesmo quando dicas para prováveis erros estão disponíveis, estes só podem ser prevenidos por meio do monitoramento acentuado e da atividade diligente do Sistema 2. [...] Questionar constantemente nosso próprio pensamento seria impossivelmente tedioso, e o Sistema 2 é vagaroso e ineficiente demais para servir como um substituto para o Sistema 1 na tomada de decisões rotineiras.

Como ressaltado, os vieses são o produto de decisões frequentemente tomadas de maneira intuitiva e o raciocínio lento, que demanda esforço e atenção, é aquele capaz de evitar tais erros sistemáticos. Todavia, conforme será demonstrado, a utilização do Sistema 2 quando da realização de uma escolha ou da resistência à tentação não apenas requer um grande esforço mental, como também consome recursos cognitivos limitados - o que prejudicará decisões subsequentes. É o que se entende na literatura por esgotamento do ego (ego depletion).

Dentre os desvios comportamentais que escapam dos padrões da teoria econômica tradicional e que podem prejudicar a tomada de decisões, relacionam-se de maneira mais direta com os objetivos deste trabalho as anomalias descritas pela Teoria dos Prospectos e os descontos intertemporais hiperbólicos.

Como será oportunamente demonstrado, os efeitos de tais vieses são, provavelmente, ampliados quando se passa pelo esgotamento do ego ${ }^{17}$ e podem criar situações extremamente perniciosas, na medida em que há fortes indícios empíricos de que o processo de esgotamento do ego é exacerbado em ambientes de pobreza extrema.

\subsection{A teoria dos prospectos e os descontos intertemporais hiperbólicos}

Antes de abordar diretamente os efeitos psicologicamente adversos da pobreza, é necessário discutir alguns aspectos comportamentais que destoam do modelo econômico tradicional. Primeiro, será abordada a Teoria dos Prospectos e a forma como ela revolucionou a compreensão do comportamento humano sob risco. Depois, será feita a análise das anomalias que são encontradas nas escolhas intertemporais.

Importante salientar que a exposição minuciosa de todos os detalhes que envolvem tais desvios comportamentais ultrapassa os fins deste trabalho. Busca-se, aqui, meramente expor os conceitos básicos que envolvem a Teoria dos Prospectos e os descontos intertemporais hiperbólicos.

\subsubsection{Decisões sob risco: a ascensão da Teoria dos Prospectos}

Em primeiro lugar, faz-se imperioso o estudo acerca da análise da tomada de decisões em condições de incerteza, no qual Bernoulli ${ }^{18}$ afirma:

Mas qualquer um que considerar o problema com perspicácia e interesse irá verificar que o conceito de valor que nós utilizamos nessa regra pode ser definido de forma a tornar todo o processo universalmente aceitável sem reservas. Para fazer isso, a determinação do valor de um item não deve ser baseada no seu preço, mas na utilidade que ele produz. O preço de um item é dependente apenas da coisa em si mesmo e é igual para todos; a utilidade, entretanto, é dependente de circunstâncias particulares da pessoa que faz a estimativa.

17 Importante ressaltar que o trabalho não pretende demonstrar empiricamente essa correlação. Indica, na verdade, as relações entre a pobreza e os vieses comportamentais, especialmente em ambientes de pobreza, como uma importante e promissora agenda de pesquisa. Com uma maior quantidade de dados, é possível chegar a resultados mais conclusivos desses efeitos.

18 BERNOULLI, Daniel. Exposition of a new theory on the measurement of risk.Econometrica, [s.l.], v. 22, n. 1, p. 22-36, jan. 1954. Disponível em: <https://engineering.purdue.edu/ ipollak/ece302/FALL09/notes/Bernoulli_1738.pdf>. p. 24. Tradução nossa. 
Enquanto isso, vamos usar essa como uma regra fundamental: Se a utilidade de cada possibilidade esperada de lucro for multiplicada pelo número de vezes em que ela pode ocorrer, e então dividirmos a soma desses produtos pelo número total de casos possíveis, uma utilidade média (expectativa moral) será obtida e o lucro que corresponde a essa utilidade será igual ao valor do risco em questão.

Bernoulli, ao expor que a utilidade do primeiro milhar de dólares que um indivíduo ganha é maior que a dos subsequentes, inaugura a noção de aversão ao risco.

Este viés é ilustrado por Thaler ${ }^{19}$, ao narrar que, caso um agente, detentor de riqueza equivalente a cem mil dólares, esteja em uma situação de escolha entre mil dólares adicionais e 50\% de chance de ganhar dois mil dólares, haverá ele de aceitar a coisa certa, porquanto o segundo milhar é menos valorizado que o primeiro, não estando o agente disposto a aceitar o risco de perder o primeiro prêmio de mil dólares em uma tentativa de ganhar o segundo.

O tratamento teórico do processo decisório em situações de risco foi publicado em 1944 por Von Neumann e Morgenstern ${ }^{20}$, que inauguraram a chamada Teoria da Utilidade Esperada - a qual viria a ser, posteriormente, objeto de uma das críticas mais contundentes da Economia Comportamental.

Segundo essa teoria, uma decisão sob risco envolve a escolha entre prospectos, que nada mais são que contratos nos quais, com uma probabilidade $P \mathrm{i}$, atinge-se o resultado $\mathrm{Xi}^{21}$. Prospectos são, portanto, distribuições probabilísticas em torno de um conjunto de consequências ${ }^{22}$. A Teoria da Utilidade Esperada apresenta três axiomas básicos, conforme descreve estudo clássico de Kahneman e Tversky ${ }^{23}$. Primeiro, a utilidade geral de um prospecto seria a utilidade esperada de seus resultados. Além disso, um prospecto seria aceitável se e somente se a utilidade resultante de integrá-lo a um ativo fosse maior que a utilidade do ativo por si só. Por fim, os agentes apresentariam uma prevalência pela aversão ao risco, na medida em que preferem o prospecto certo $\mathrm{X}$ a qualquer prospecto arriscado de valor esperado $\mathrm{X}$.

Sendo assim, para a Teoria da Utilidade Esperada, o comportamento humano buscaria maximizar uma função de valor definida em torno dos prospectos. Os agentes atribuiriam utilidades subjetivas às consequências possíveis dos riscos e a avaliação da utilidade esperada de cada prospecto seria formada pela média das utilidades de seus resultados, ponderados conforme as suas probabilidades ${ }^{24}$. Dessa forma, segundo Kahneman ${ }^{25}$ :

A coisa fica mais interessante, porém, porque há um poderoso argumento de que um tomador de decisão que deseja ser racional deve se conformar ao princípio da expectativa. Esse foi o ponto principal da versão axiomática da teoria da utilidade que Von Neumann e Morgenstern apresentaram em 1944. Eles provaram que qualquer ponderação de resultados que não seja estritamente proporcional à probabilidade leva a inconsistências e outros desastres. A derivação feita por eles do princípio de expectativa a partir de axiomas de escolha racional foi imediatamente reconhecida como uma realização monumental, o que situou a teoria da utilidade esperada no âmago do modelo de agente racional em economia e outras ciências sociais.

Kahneman e Tversky, ao longo de todo o seu trabalho em conjunto, demonstraram diversas situações

19 THALER, Richard.Misbehaving:the making of behavioral economics. Nova Iorque: W. W. Norton, 2016. p. 28-29.

20 VON NEUMANN, John; MORGENSTERN, Orkas. Theory of games and economic behavior.Princeton: Princeton University Press, 1953.

21 KAHNEMAN, Daniel; TVERSKY, Amos. Prospect theory: an analysis of decision under risk.Econometrica, [s.l.], v. 47, n. 2, p. 263-292, mar. 1979. Disponível em: <http://people.hss.caltech.edu/ camerer/Ec101/ProspectTheory.pdf>. p. 263-264.

22 STARMER, Chris. Entendendo preferências: o que podemos aprender com a economia comportamental?. In: ÁVILA, Flávia; BIANCHI, Ana Maria.Guia de Economia Comportamental e Experimental.São Paulo: Economiacomportamental.org, 2015. p. 60-75. p. 63.

23 KAHNEMAN, Daniel; TVERSKY, Amos. Prospect theory: an analysis of decision under risk.Econometrica, [s.l.], v. 47, n. 2, p. 263-292, mar. 1979. Disponível em: <http://people.hss.caltech.edu/ camerer/Ec101/ProspectTheory.pdf>. p. $263-264$.

24 STARMER, Chris. Entendendo preferências: o que podemos aprender com a economia comportamental?. In: ÁVILA, Flávia; BIANCHI, Ana Maria.Guia de Economia Comportamental e Experimental.São Paulo: Economiacomportamental.org, 2015. p. 60-75. p. 63.

25 KAHNEMAN, Daniel.Rápido e devagar:duas formas de pensar. Rio de Janeiro: Objetiva, 2012. p. 390. 
em que os axiomas da Teoria da Utilidade Esperada eram frequentemente violados. Contudo, embora seu êxito como teoria normativa em relação ao comportamento humano ${ }^{26}$, não era frutífera em seu âmbito descritivo, sendo incapaz de prever como seriam as escolhas reais dos seres humanos ${ }^{27}$. Kahneman e Tversky propuseram, em seguida, a Teoria dos Prospectos, que não pretendia ser um guia para a escolha racional, mas sim descrever adequadamente como seria o comportamento humano.

A Teoria dos Prospectos gravita torno de três características cognitivas, conforme é exposto por Kahne$\operatorname{man}^{28}$. Primeiro, as avaliações são realizadas conforme um ponto de referência neutro: o nível de adaptação. Assim, em relação a resultados financeiros, por exemplo, o ponto de referencia é, em geral, o status quo, mas também pode ser o resultado que é esperado ou ao qual o sujeito pensa ter direito. Além disso, há um princípio de sensibilidade decrescente aplicável tanto às dimensões sensoriais quanto à avaliação de mudanças de riqueza. Por exemplo, a diferença subjetiva entre novecentos e mil reais será muito menor que a existente entre cem e duzentos. Por fim, há uma assimetria entre as perdas e os ganhos, isto é, os humanos possuem aversão à perda, de forma que sentem mais intensamente as perdas que os ganhos.

Sugere o autor, então, duas situações de escolha que ilustram a Teoria dos Prospectos, colocando um dado agente, a primeiro, a decidir se optaria por possuir, indubitavelmente, novecentos dólares, ou 90\% de chance de conseguir mil dólares; a segundo, a optar por uma perda inevitável de novecentos dólares, ou 90\% de chance de perder mil dólares ${ }^{29}$.

Conforme exposto por Kahneman ${ }^{30}$, as respostas a esses problemas expõem a essência da Teoria dos Prospectos. No problema 1, a utilidade esperada do ganho de novecentos dólares é, certamente, maior que $90 \%$ da utilidade do ganho de mil dólares. Isso leva a um comportamento avesso ao risco. No problema 2, por sua vez, a utilidade esperada (negativa) de perder novecentos dólares é, consideravelmente, maior do que a utilidade (negativa) de perder mil dólares. Isso porque há a aversão à perda e, logo, tem-se, nessa situação, um comportamento que busca o risco.

Logo, segundo a Teoria dos Prospectos, escolhas extremamente avessas ao risco aparecerão em casos de apostas mistas, em que tanto ganhos quanto perdas são possíveis; já nos casos de escolhas ruins - perda segura comparada com a possibilidade de uma perda maior -, vê-se a atração ao risco, provocada pela sensibilidade decrescente ${ }^{31}$.

Kahneman ${ }^{32}$ aponta que não há qualquer contradição nessas duas situações. Isso porque, no caso misto, as perdas assomam um valor aproximadamente duas vezes maior que os ganhos. Já no caso de escolhas ruins, a sensibilidade decrescente causa atração ao risco, na medida em que a dor de perder novecentos dólares é maior do que $90 \%$ da dor de perder mil dólares.

Para complementar um panorama geral da Teoria dos Prospectos, deve-se discorrer, brevemente, sobre os efeitos da possibilidade e da certeza e sobre o Padrão Quádruplo (fourfold pattern). Todos esses elementos fazem parte da avaliação global de uma perspectiva incerta e de como são atribuídos pesos aos seus resultados. A fim de compreendê-los, Daniel Kahneman ${ }^{33}$ sugere a situação abaixo:

Nos quatro exemplos abaixo, suas chances de receber um milhão melhoram em $5 \%$. As notícias são igualmente boas em cada caso?

A. De 0 a $5 \%$

26 No sentido de estabelecer como seria a maneira correta de se pensar cerca de um problema, isto é, a maneira logicamente consistente.

27 THALER, Richard.Misbehaving:the making of behavioral economics. Nova Iorque: W. W. Norton, 2016. p. 25-29.

28 KAHNEMAN, Daniel.Rápido e devagar:duas formas de pensar. Rio de Janeiro: Objetiva, 2012. p. 350-351.

29 KAHNEMAN, Daniel.Rápido e devagar:duas formas de pensar. Rio de Janeiro: Objetiva, 2012. p. 348.

30 KAHNEMAN, Daniel.Rápido e devagar:duas formas de pensar. Rio de Janeiro: Objetiva, 2012. p. 348.

31 KAHNEMAN, Daniel.Rápido e devagar:duas formas de pensar. Rio de Janeiro: Objetiva, 2012. p. 354.

32 KAHNEMAN, Daniel.Rápido e devagar:duas formas de pensar. Rio de Janeiro: Objetiva, 2012. p. 354-355.

33 KAHNEMAN, Daniel.Rápido e devagar:duas formas de pensar. Rio de Janeiro: Objetiva, 2012. p. 388. 
B. De $5 \%$ a $10 \%$

C. De $60 \%$ a $65 \%$

D. De $95 \%$ a $100 \%$

Pelo princípio da expectativa, exposto por Bernoulli e axiomatizado por Von Neumann e Morgenstern, em todos os casos há um aumento de utilidade exatamente igual a 5\% da utilidade de receber um milhão. Evidentemente, essa previsão não é parecida à lógica de decisões de um Homo Sapiens.

Nitidamente, as opções A e D impressionam mais que as demais. Conforme é descrito ${ }^{34}$, o efeito impactante de $0 \%$ a $5 \%$ é ilustrativo do efeito de possibilidade (possibility effect), que faz com que as pessoas atribuam um peso desproporcional a resultados altamente improváveis, como em casos de jogos em loteria. $\mathrm{Na}$ de $95 \%$ para 100\%, no entanto, é possível perceber o efeito de certeza (certainty effect). Por meio dele, resultados praticamente certos recebem um peso menor do que é justificável pelas suas probabilidades.

Kahneman ${ }^{35}$, então, conclui:

A conclusão é inequívoca: os pesos de decisão que as pessoas atribuem a resultados não são idênticos às probabilidades desses resultados, contrariamente ao princípio de expectativa. Resultados improváveis recebem peso excessivo - isso é o efeito da possibilidade. Resultados que são quase certos recebem peso insuficiente em relação à certeza existente.

Diante desse quadro, dois elementos se destacam na Teoria da Perspectiva: as pessoas atribuem valores a ganhos e perdas e não à riqueza; e os pesos de decisão não são exatamente iguais às probabilidades. A combinação desses dois fatores explica um padrão distintivo de preferências que ficou conhecido como padrão quádruplo e que pode ser resumido, oportunamente, no seguinte esquema ${ }^{36}$ :

1) Alta probabilidade (efeito certeza) de ganhos ( $95 \%$ de chance de ganhar dez mil dólares) e efeito certeza implicam em aversão ao risco, e podem levar, por exemplo, à aceitação de acordos desfavoráveis.

2) Alta probabilidade (efeito certeza) de perdas ( $95 \%$ de chance de perder dez mil dólares) e a esperança de evitar a perda levam o sujeito à busca do risco e, eventualmente, à rejeição de acordos favoráveis.

3) Baixa probabilidade (efeito possibilidade) de ganhos (5\% de chance de ganhar dez mil dólares) e a esperança de grande ganho levam à busca de risco e, eventualmente, à rejeição de acordos favoráveis.

4) Baixa probabilidade de perdas (efeito possibilidade) e o medo de se ter que se desfazer daquilo que já possui leva o gente a ser avesso ao risco e, eventualmente, a aceitar acordos desfavoráveis.

Nesse contexto, algumas conclusões podem ser extraídas ${ }^{37}$. A situação (1) expõe o que era discutido por Bernoulli. Diante de uma perspectiva substancial de ganho, as pessoas são avessas ao risco e estão dispostas a aceitar menos do que o valor esperado de uma aposta para assegurar a certeza do ganho. Já a situação (3) demonstra o efeito da possibilidade e explica a popularidade das loterias. Na situação (4), há a compra da segurança. Os humanos tendem a pagar mais para ter segurança do que o valor esperado - e isso tende a explicar o motivo pelo qual as companhias de seguro conseguem o seu lucro. A situação (2) ilustra o caso das escolhas ruins. Justifica-se por conta da sensibilidade decrescente, que torna a perda certa extremamente aversiva, e por conta do efeito de certeza, que reduz a aversividade da aposta.

Expostas as características gerais da Teoria dos Prospectos e de sua crítica à Teoria da Utilidade Esperada, será feita a análise dos descontos intertemporais hiperbólicos.

34 KAHNEMAN, Daniel.Rápido e devagar:duas formas de pensar. Rio de Janeiro: Objetiva, 2012. p. 388-389.

35 KAHNEMAN, Daniel.Rápido e devagar:duas formas de pensar. Rio de Janeiro: Objetiva, 2012. p. 389.

36 KAHNEMAN, Daniel.Rápido e devagar:duas formas de pensar. Rio de Janeiro: Objetiva, 2012. p. 395.

37 KAHNEMAN, Daniel.Rápido e devagar:duas formas de pensar. Rio de Janeiro: Objetiva, 2012. p. 396-397. 


\subsubsection{Anomalias em escolhas intertemporais: descontos hiperbólicos}

The pleasure which we are to enjoy ten years hence interests us so little in comparison with that which we may enjoy to-day [...]- Adam Smith ${ }^{38}$

Em muitas situações, os custos e benefícios de uma escolha diluem-se no tempo. São as chamadas escolhas intertemporais, que têm como exemplos clássicos a realização, em prol de um futuro tranquilo, de exercícios físicas, de dietas, ou mesmo de poupança. Em todos esses casos - e em muitos outros -, aos esforços despendidos para uma dada atividade não se seguem recompensas imediatas.

O modelo econômico tradicional moderno acerca das escolhas intertemporais foi esboçado por Samuel$\operatorname{son}^{39}$ e denominou-se como "Modelo da Utilidade Descontada Constante"

A principal premissa do modelo da utilidade descontada é que o consumo atual seria mais valorizado pelo indivíduo, se comparado ao futuro ${ }^{41}$. Haveria, então, um desconto do consumo futuro em algum percentual.

Conforme exposto por Faveri ${ }^{42}$ :

O modelo de utilidade descontada constante (MUDC) foi elaborado com o intuito de representar simplificadamente os eventos das escolhas intertemporais, supondo que em cada momento do tempo a satisfação do agente depende exclusivamente do seu consumo naquele momento e que os agentes maximizam o somatório das utilidades descontadas (SAMUELSON, 1937). A utilidade descontada consiste em maximizar o somatório das utilidades de cada período e calcular o seu valor presente (MURAMATSU; FONSECA, 2009).

O exemplo dado por Thaler ${ }^{43}$ ilustra a teoria:

Para entender como funciona o desconto, suponha que exista algum bem, talvez a chance de assistir a uma partida de tênis em Wimbledon. Se a partida for assistida hoje à noite, valeria 100 utils, as unidades arbitrárias utilizadas pelos economistas para descrever níveis de utilidade ou de felicidade. Considere Ted, que desconta a uma taxa constante de $10 \%$ ao ano. Para ele, essa partida valeria 100 utils este ano, 90 no próximo ano, depois 81,72 e assim por diante. Diz-se que, quando alguém desconta a utilidade dessa maneira, está descontando com uma função exponencial.

Nesse caso, é possível dizer que há descontos numa função exponencial, que caracteriza o Modelo de Utilidade Descontada Constante, e haveria, então, "trade-offs explícitos entre os custos e os benefícios que ocorrem em momentos distintos" $"$.

Entretanto, tal como demonstrado experimentalmente pela Economia Comportamental, os humanos não se parecem com o Homo Economicus e cometem erros previsíveis e sistemáticos. São exemplos de anomalias frente ao Modelo de Utilidade Descontada Constante, por exemplo ${ }^{45}$, a miopia, quando se tem preferências enviesadas ao consumo presente; o efeito sinal, no qual as preferências temporais dependem da

38 SMITH, Adam.The theory of moral sentiments.São Paulo: Metalibri, 2006. Disponível em: <https://www.ibiblio.org/ml/libri/s/ SmithA_MoralSentiments_p.pdf>.p. 170.

39 SAMUELSON, Paul A. A note on measurement of utility.The Review of Economic Studies, [s.l], v. 4, n. 2, p. 155-161, fev. 1937. Publicado pela Oxford University Press. Disponível em: <http://www.jstor.org/stable/2967612>.

40 Expor as minúcias da teoria de Samuelson ultrapassa os objetivos deste trabalho. Sendo assim, serão delineadas as suas ideias básicas e, posteriormente, as críticas da Economia Comportamental.

41 THALER, Richard.Misbehaving:the making of behavioral economics. Nova Iorque: W. W. Norton, 2016. p. 89.

42 DE FAVERI, Dinorá Baldo.Impaciência nas escolhas intertemporais:uma abordagem comportamental. 2017. 227 f. Tese (Doutorado) - Curso de Programa de Pós-graduação em Economia, Universidade Federal de Santa Catarina, Florianópolis, 2017. Disponível em: <https://repositorio.ufsc.br/bitstream/handle/123456789/183406/349814.pdf?sequence=1 $>$.

43 THALER, Richard.Misbehaving:the making of behavioral economics. Nova Iorque: W. W. Norton, 2016. Tradução nossa.

44 RICK, Scott; LOEWENSTEIN, George. Intangibilidade na escolha intertemporal. In: ÁVILA, Flávia; BIANCHI, Ana Maria. Guia de economia comportamental e experimental.São Paulo: Economiacomportamental.org, 2015. p. 76-97. p. 76.

45 MURAMATSU, Roberta; FONSECA, Patrícia. Economia e psicologia na explicação da escolha intertemporal.Revista de Economia Mackenzie, São Paulo, v. 6, n. 6, p. 87-112. 2008. Disponível em: <http://editorarevistas.mackenzie.br/index.php/rem/article/ view/810>. p. 93. 
percepção de ganho ou perda ou, ainda, o viés de projeção, em que as preferencias futuras são estimadas de acordo com estados sensoriais e fisiológicos do agente - como o clima a que ele está exposto.

A partir dessas anomalias, um novo modelo foi proposto para explicar os descontos intertemporais com base em como eles são na realidade. No novo sistema, denominado modelo dos descontos hiperbólicos, os indivíduos possuem uma taxa decrescente de preferência no tempo. Conforme explicam Frederick, Loewenstein e O'Donoghue ${ }^{46}$ :

Alguns resultados são usualmente interpretados como evidência para o desconto hiperbólico. Primeiro, quando se solicita a participantes que comparem entre uma recompensa menor e mais atual e uma recompensa maior e futura [...], a taxa implícita de desconto em horizontes maiores de tempo é menor que a taxa implícita em horizontes menores de tempo. [...] Segundo, quando funções matemáticas são explicitamente adequadas a esses dados, uma forma funcional hiperbólica, que impõe descontos decrescentes, adequa-se melhor aos dados que a forma funcional exponencial, que impõe taxas constantes de desconto. [...] Terceiro, pesquisadores têm mostrado que preferências entre duas recompensas atrasadas podem reverter-se em favor de uma recompensa mais próxima, como o tempo para ambas as recompensas diminui - e.g., alguém pode preferir $\$ 110 \mathrm{em} 31$ dias a $\$ 100 \mathrm{em} 30$ dias, mas também preferir $100 \$$ agora a $\$ 110$ amanhã.

Nesse quadro, ao serem analisados os exemplos mais importantes de escolhas intertemporais, pode-se delinear um padrão que parece ser capaz de explicar as razões pelas quais as pessoas tendem a descontar o futuro em taxas decrescentes. Na maior parte dos casos, enquanto os resultados preliminares tendem a ser concretos, como no caso de comprar um produto ou de consumir uma droga que causa dependência química, os resultados posteriores tendem a ser intangíveis ou indefinidos, por exemplo, a obesidade ou a dependência química ${ }^{47}$.

Conforme ressaltam Rick e Loeweinstein ${ }^{48}$, tal intangibilidade pode ter diferentes causas. Por vezes, é devida à imperceptibilidade do impacto do comportamento, como ocorre com o consumo de uma refeição em relação ao futuro ganho de peso. Em algumas situações, há dificuldade ou impossibilidade de se imaginar as consequências futuras, como quando há o dispêndio de dinheiro em vez da poupança. Por fim, outros casos possuem tal natureza pela incerteza inerente às suas consequências, por exemplo, o consumo de substâncias químicas e a dependência.

Por fim, para compreender como ocorrem os descontos hiperbólicos, considere outro exemplo dado por Thaler ${ }^{49}$ :

Suponha que Ted e Matthew morem em Londres e sejam ávidos fãs de tênis. Cada um ganhou um sorteio oferecendo um ingresso para uma partida em Wimbledon, com um fator intertemporal. Eles podem escolher entre três opções. A opção A é um bilhete para uma partida da primeira rodada neste ano; na verdade, a partida é amanhã. A opção B é uma partida de quartas de final no torneio do próximo ano. A opção C é a final, no torneio que será realizado daqui a dois anos. Todos os ingressos são garantidos, então podemos deixar as considerações de risco fora de nossa análise, e Ted e Matthew têm gostos idênticos no tênis. Se os jogos forem todos para o torneio deste ano, as utilidades que eles atribuem a eles são os seguintes: A: 100, B: 150, C: 180. Mas, para ir para a sua opção favorita C, a final do torneio, eles têm que esperar dois anos. O que eles farão?

Se Ted tivesse escolha, ele escolheria esperar dois anos e ter o ingresso para a final. Ele o faria porque o valor atribuído no momento para a final em dois anos (o seu "valor presente") é 146 (81\% de 180), o

46 FREDERICK, Shane; LOEWENSTEIN, George; O'DONOGHUE, Ted. Time discounting and time preference: a critical review.Journal of Economic Literature, [s.l.], v. 40, n. 2, p. 351-401, jun. 2002. American Economic Association. Disponível em: < http:// dx.doi.org/10.1257/002205102320161311>. p. 360-361. Tradução nossa.

47 RICK, Scott; LOEWENSTEIN, George. Intangibilidade na escolha intertemporal. In: ÁVILA, Flávia; BIANCHI, Ana Maria. Guia de economia comportamental e experimental.São Paulo: Economiacomportamental.org, 2015. p. 76-97. p. 77.

48 RICK, Scott; LOEWENSTEIN, George. Intangibilidade na escolha intertemporal. In: ÁVILA, Flávia; BIANCHI, Ana Maria. Guia de economia comportamental e experimental.São Paulo: Economiacomportamental.org, 2015. p. 76-97. p. 77.

49 THALER, Richard.Misbehaving:the making of behavioral economics. Nova Iorque: W. W. Norton, 2016. p. 92. Grifo nosso. Tradução nossa. 
que é mais significativo que o valor atual de A (100) e de B (135, ou 90\% de 150). Além disso, após um ano, se questionado acerca da possibilidade de mudar a sua escolha e aceitar a opção B, as quartas de final, ele negaria, na medida em que $90 \%$ do valor de C (162) é ainda maior que o valor de B. Isso é o que significa ter preferencias consistentes no tempo. [...]

E quanto a Matthew? Quando primeiro apresentado à escolha, ele também escolheria a opção C, a final. No momento, ele avalia A em 100, B em 105 (70\% de 150) e C em 113 (63\% de 180). Mas ao contrário de Ted, quando um ano se passa, Matthew mudará de opinião e trocará para B, as quartas de final, porque esperar um ano desconta o valor de $\mathrm{C}$ em $70 \%$ de 126 , o que é menor que 150, o atual valor de B. Ele é inconsistente no tempo.

Expostos os conceitos básicos que envolvem as escolhas intertemporais, bem como o modelo econômico-comportamental que descreve o comportamento humano nessas situações, resta tratar acerca das limitações do autocontrole e do esgotamento do ego.

\subsection{O esgotamento do ego}

O experimento de Danzinger, Levav e Avnaim-Pesso ${ }^{50}$ é um exemplo significativo para se introduzir a temática do esgotamento do ego. Os autores questionam se os resultados de casos judiciais seriam determinados apenas pelos fatos e pelo Direito ou se fatores alheios também teriam o seu impacto. Para tanto, analisaram os padrões decisórios de juízes, que passavam o dia todo revisando pedidos de condicional. O resultado da pesquisa foi esclarecedor:

Apresentamos evidências sugerindo que quando juízes realizam decisões repetidas, eles possuem uma considerável tendência para julgar a favor do status quo. Essa tendência pode ser superada por uma pausa para refeições, o que é consistente com pesquisas anteriores demonstrando os efeitos de um rápido descanso, do bom humor e da glicose para a reposição das reservas mentais. ${ }^{51}$

Os resultados mostram que mesmo juízes, no exercício da função para qual foram preparados, demonstram reduzida capacidade decisória após exercerem significativo esforço cognitivo. Além disso, também é possível perceber que o repouso e a alimentação parecem estar relacionados ao retorno da capacidade cognitiva decisória inicial ${ }^{52}$.

Esse fenômeno foi extensamente demonstrado experimentalmente ${ }^{53}$. Baumeister et al. ${ }^{54}$ utilizam o termo Ego Depletion, aqui traduzido como Esgotamento do Ego, para se referir à redução temporária na capacidade do self $\tilde{f}^{5}$ ou na vontade de iniciar uma ação volitiva, provocada por prévio exercício volitivo.

Os autores citados adotaram como premissa que o self consome uma reserva limitada, semelhante a uma energia ou força, quando realiza atos de volição. Para isso, testaram a hipótese de que atos de escolha e de autocontrole causariam o esgotamento do ego. Mais especificamente, de que após um ato inicial de volição,

50 DANZINGER, Shai; LEVAV, Jonathan; AVNAIM-PESSO, Liora. Extraneous factors in judicial decisions. Proceedings of The National Academy of Sciences of the United States of America, Princeton, v. 108, n. 17, p. 6889-6892, 26 abr. 2011.

51 DANZINGER, Shai; LEVAV, Jonathan; AVNAIM-PESSO, Liora. Extraneous factors in judicial decisions.Proceedings of The National Academy of Sciences of the United States of America, Princeton, v. 108, n. 17, p. 6889-6892, 26 abr. 2011. p. 6892. Tradução nossa.

52 Os autores ressaltam que não é possível determinar de maneira inequívoca se o simples descanso ou a alimentação restauram as reservas mentais dos juízes porque cada uma das pausas foi realizada para o propósito de fazer uma refeição.

53 Para uma extensa revisão bibliográfica acerca do esgotamento do ego, ver:

BAUMEISTER, Roy F; TIERNEY, John.Willpower:rediscovering the greatest human strength. [s.l.]: Penguin Books, 2012.

54 BAUMEISTER, Roy F. et al. Ego depletion: is the active self a limited resource?Journal of Personality and Social Psychology, [s.l.], v. 74 , n. 5 , p. $1252-1265$, maio 1998. p. 1253.

55 Vale ressaltar que self, na terminologia utilizada pelos autores, de nítida influência freudiana, estaria relacionado às escolhas, decisões e comportamentos inibitórios; à realização de planos e à execução destes. Ainda que nem todo o comportamento humano envolva controles deliberados pelo self, uma parte importante do comportamento assim o faz. Não se adota, neste trabalho, uma perspectiva psicanalítica de análise. O que é considerado pelos autores como atuação do self, aqui, é equiparado à atuação do Sistema 2. 
haveria menor reserva mental para os atos subsequentes ${ }^{56}$. Dos experimentos realizados pelos autores, três deles merecem ser destacados.

O primeiro teve por objeto o autocontrole. No grupo de tratamento, os participantes resistiram ao impulso de comer chocolates colocados à sua frente e, em vez disso, esforçaram-se para comer rabanetes. Após essa etapa, as pessoas tiveram que realizar um quebra-cabeça de alto grau de dificuldade. As pessoas que haviam resistido à tentação desistiram muito mais rápido, em comparação com aquelas que puderam comer os chocolates ou que não se submeteram a essa tentação ${ }^{57}$. O experimento demonstrou com êxito, segundo os autores, que o autocontrole, nas duas situações, usa a mesma fonte limitada, de tal forma que a realização de um dos atos impacta no ato subsequente.

No segundo experimento, pretendeu-se testar se um ato de escolha pessoal produziria o mesmo efeito visto no primeiro experimento. Foram solicitados a dois grupos que consentissem livre e deliberadamente a realizar um discurso, favorável ou contrário aos seus pontos de vista pessoais. Um terceiro grupo continha indivíduos que deveriam elaborar discursos, conforme o tema indicado pelos pesquisadores, sem a opção de realizarem uma escolha para tanto. No grupo de participantes que realizaram uma escolha livre e deliberada, foram encontradas maiores taxas de desistência no mesmo desafio do primeiro experimento ${ }^{58}$. Assim, concluíram que fazer uma escolha também parece ser um ato que utiliza a mesma reserva mental que é gasta ao se exercer o autocontrole.

O terceiro experimento pretendeu demonstrar que o prévio exercício de autocontrole impactaria a posterior tomada de decisões. Para isso, o grau de predominância da opção passiva foi mensurado. Pessoas foram expostas a situações de escolha em que deveriam responder ativa ou passivamente. Aquelas que estavam com o ego esgotado, por tarefas semelhantes às realizadas nos dois experimentos narrados anteriormente, apresentavam uma tendência a utilizar as respostas passivas ${ }^{59}$. Para os pesquisadores, as escolhas ativas também consomem a mesma reserva mental consumida pelas demais atividades volitivas, de forma que as pessoas tendem a permanecer mais passivas quanto mais escassos esses recursos forem.

Com estes exemplos, Baumeister et al. ${ }^{60}$ ilustram um padrão amplo do esgotamento do ego:

Tomados em conjunto, esses quatro estudos apontam para um padrão amplo de esgotamento do ego. Em cada um deles, um ato inicial de volição foi seguido por um prejuízo em alguma outra esfera da volição. Nós verificamos que um ato inicial de autocontrole prejudicou o autocontrole subsequente (Estudo 1), que realizar uma decisão responsável prejudicou o autocontrole subsequente (Estudo 2), que o autocontrole diminuiu o desempenho em uma tarefa que requereu autocontrole (Estudo 3), e que um ato inicial de autocontrole leva a uma passividade aumentada (Estudo 4).

Conforme exposto por Kahneman, atividades que impõem altas exigências ao Sistema 2, como escolhas deliberadas e resistir a tentações, requerem autocontrole, o que é exaustivo e desagradável ${ }^{61}$. Constata-se, por exemplo, que pessoas com o ego esgotado têm maior probabilidade de fazer escolhas egoístas, de utilizar linguajar sexista e de fazer julgamentos superficiais socialmente ${ }^{62}$. Kahneman alerta, ainda, que o relaxamento do controle do Sistema 2 - isto é, o esgotamento do ego - não é o único responsável por enfraquecer o

56 BAUMEISTER, Roy F. et al. Ego depletion: is the active self a limited resource?Journal of Personality and Social Psychology, [s.1.], v. 74, n. 5, p. 1252-1265, maio 1998. p. 1253.

57 BAUMEISTER, Roy F. et al. Ego depletion: is the active self a limited resource?Journal of Personality and Social Psychology, [s.l.], v. 74, n. 5, p. 1252-1265, maio 1998. p. 1261.

58 BAUMEISTER, Roy F. et al. Ego depletion: is the active self a limited resource?Journal of Personality and Social Psychology, [s.l.], v. 74, n. 5, p. 1252-1265, maio 1998. p. 1261-1262.

59 BAUMEISTER, Roy F. et al. Ego depletion: is the active self a limited resource?Journal of Personality and Social Psychology, [s.l.], v. 74 , n. 5 , p. 1252-1265, maio 1998. p. 1262.

60 BAUMEISTER, Roy F. et al. Ego depletion: is the active self a limited resource?Journal of Personality and Social Psychology, [s.l.], v. 74, n. 5, p. 1252-1265, maio 1998. p. 1262. Tradução nossa.

61 KAHNEMAN, Daniel.Rápido e devagar:duas formas de pensar. Rio de Janeiro: Objetiva, 2012. p. 56.

62 KAHNEMAN, Daniel.Rápido e devagar:duas formas de pensar. Rio de Janeiro: Objetiva, 2012. p. 55. 
autocontrole. Por exemplo, algumas doses de álcool ou uma noite insone podem produzir o mesmo efeito ${ }^{63}$.

Contribui com a presente análise o experimento conduzido por Hamilton, Hong e Chernev $^{64}$, com o objetivo de testar se as opções de escolha variariam conforme se escolhe de modo intuitivo ou de modo deliberado. Colhidos os dados, demonstrou-se que estar com o ego esgotado é semelhante a utilizar o Sistema 1: participantes que escolherem com o ego esgotado apresentaram padrões decisórios indistinguíveis daqueles apresentados pelos participantes do grupo que escolhia intuitivamente e ambos eram diversos daqueles apresentados pelos participantes que escolhiam de forma deliberada ${ }^{65}$.

Importante ressaltar que experimentos descartaram algumas explicações alternativas para o padrão de comportamento apresentado com o esgotamento do ego. Por exemplo, efeitos de humor e o sentimento de superdedicação para o experimento ${ }^{66}$ ou o sentimento de ter falhado na primeira tarefa e, logo, de estar com o autocontrole diminuído ${ }^{67}$.

Os recursos mentais consumidos no esgotamento do ego são, normalmente, repostos. As pesquisas originais que identificavam tal fenômeno não determinavam qual seriam os fatores envolvidos nessa reposição $^{68}$. Estudos posteriores ${ }^{69}$, no entanto, apontaram uma correlação entre os níveis de glicose e o esgotamento do ego. Nesse sentido, Kahneman ${ }^{70}$ afirma:

O sistema nervoso consome mais glicose do que outras partes do corpo, e a atividade mental trabalhosa parece ser particularmente dispendiosa na moeda da glicose. Quando você está ativamente envolvido em um raciocínio cognitivo difícil ou ocupado numa tarefa que exige autocontrole, seu nível de glicose no sangue cai. O efeito é análogo a um corredor que suga a glicose armazenada em seus músculos num tiro. A implicação óbvia dessa ideia é que os efeitos do esgotamento do ego podem ser anulados com a ingestão de glicose, e Baumeister e seus colegas confirmaram essa hipótese em diversos experimentos.

Em um desses estudos, Gailliot $e t$ al. ${ }^{71}$ encontraram evidências de que o controle de atenção requer uma quantidade relativamente grande de glicose. Nesse experimento, participantes assistiram a um vídeo de 6 minutos e lhes foi proposto ou que ignorassem um certo estímulo aparecendo na tela ou que assistissem ao vídeo normalmente. Entre os participantes que realizaram o controle de atenção, o nível de glicose diminuiu após realizarem a tarefa, enquanto o outro grupo não apresentou qualquer alteração.

A conclusão desta pesquisa, assim como a de várias outras, é que baixos níveis de glicose no cérebro parecem estar associados a prejuízos no autocontrole. Assim, restaurada a quantidade disponível de glicose para níveis mais altos, o autocontrole deve melhorar. Frise-se, contudo, que o consumo de glicose para além do necessário não implica em incrementos de autocontrole, de tal forma que o efeito é observado apenas quando se disponibiliza glicose suficiente para se recuperar de um estado de ego esgotado ${ }^{72}$.

Pelo impacto que produz no processo decisório, prejudicando as decisões deliberadas, os efeitos do

63 KAHNEMAN, Daniel.Rápido e devagar:duas formas de pensar. Rio de Janeiro: Objetiva, 2012. p. 55.

64 HAMILTON, Ryan; HONG, Jiewen; CHERNEV, Alexander. Perceptual focus effects in choice.Journal of Consumer Research, [s.l.], v. 34, n. 2, p. 187-199, ago. 2007. Oxford University Press (OUP).

65 BAUMEISTER, Roy F. et al. Free will in consumer behavior: Self-control, ego depletion, and choice. Journal of Consumer Psychology, [s.l.], v. 18 , n. 1, p. 4-13, jan. 2008. p. 9.

66 BAUMEISTER, Roy F. et al. Self-regulation and personality: how interventions increase regulatory success, and how depletion moderates the effects of traits on behavior.Journal of Personality, [s.l.], v. 74, n. 6, p. 1773-1802, dez. 2006.

67 WALLACE, Harry M.; BAUMEISTER, Roy F. The effects of success versus failure feedback on further self-control.Self and Identity, [s.l.], v. 1, n. 1, p. 35-41, jan. 2002.

68 BAUMEISTER, Roy F. et al. Ego depletion: is the active self a limited resource?Journal of Personality and Social Psychology, [s.l.], v. 74 , n. 5, p. 1252-1265, maio 1998. p. 1264.

69 Vide: GAILLIOT, Matthew T.; BAUMEISTER, Roy F. The physiology of willpower: linking blood glucose to self-control. Personality and Social Psychology Review, [s.l.], v. 11, n. 4, p. 303-327, nov. 2007. SAGE Publications.

70 KAHNEMAN, Daniel.Rápido e devagar:duas formas de pensar. Rio de Janeiro: Objetiva, 2012. p. 57.

71 GAILLIOT, Matthew T. et al. Self-control relies on glucose as a limited energy source: willpower is more than a metaphor. Journal of Personality and Social Psychology, [s.1.], v. 92, n. 2, p. 325-336, 2007. American Psychological Association (APA).

72 GAILLIOT, Matthew T.; BAUMEISTER, Roy F. The physiology of willpower: linking blood glucose to self-control.Personality and Social Psychology Review, [s.l.], v. 11, n. 4, p. 303-327, nov. 2007. SAGE Publications. p. 306-307. 
esgotamento do ego podem ser identificados em diversas áreas. Diversos são os exemplos identificados no âmbito do consumo. Vohs e Faber ${ }^{73}$ demonstraram que o esgotamento do ego provoca um aumento nos gastos impulsivos. Vohs e Heatherton ${ }^{74}$, por sua vez, constataram que pessoas em dieta tendem a sair dela quando estão esgotadas. Baumeister $e$ al. constataram ${ }^{75}$ que consumidores esgotados tendem a utilizar menos a sua capacidade de raciocinar e de se informar em suas decisões de consumo, podendo simplificar suas escolhas, baseando-se apenas nos preços e ignorando outros fatores que poderiam levar a uma solução ótima, como as qualidades do produto.

O esgotamento do ego, como já ressaltado, manifesta-se por conta do uso das ferramentas cognitivas em processos decisórios complexos, e prejudica as decisões subsequentes. Como será demonstrado a seguir, esse efeito pode se tornar perverso na medida em que se analisam as escolhas econômicas feitas por pessoas em situação de pobreza.

\section{EFEITOS PSICOLOGICAMENTE ADVERSOS DA POBREZA}

A condição de maior escassez, encontrada na pobreza, traz como implicação direta uma maior complexidade em grande parte das escolhas econômicas. Conforme será demonstrado adiante, enquanto decisões simples, como comprar ou não um sabão, não trazem maiores consequências para os cidadãos mais ricos, podem ser angustiantes para um sujeito na zona rural da Índia ${ }^{76}$.

A chave para se entender a questão é o conceito de custo de oportunidade. O custo de oportunidade de um determinado bem ou serviço é aquilo que o agente abre mão ao fazer uma escolha ${ }^{77}$. Pela análise econômica tradicional, os custos de oportunidade são os grandes motivadores de todas as decisões. A Economia Comportamental, entretanto, vem demonstrando que os humanos, na verdade, não são capazes de avaliar tais custos em diversas situações cotidianas ${ }^{78}$.

Mullainathan e Shafir ${ }^{79}$ ressaltam, entretanto, que, como a Economia como um todo é entendida à luz da mentalidade da escassez, os seus pressupostos tradicionais são vistos de maneira mais real nos indivíduos submetidos a maior escassez. Por isso, pessoas pobres se comportariam de maneira mais semelhante ao Homo Economicus, no sentido de tentar atingir melhores resultados no dia-a-dia e fazer o dinheiro, escasso, render mais. Ao mesmo tempo, agir desta forma faz com que pessoas em situação de pobreza estejam submetidas a trade-offs mais graves cotidianamente, impactando, conforme será demonstrado adiante, a sua forma de decidir.

Spears ${ }^{80}$ conduziu experimento de campo a fim de analisar a sensibilidade a preços de indivíduos nos distrito indiano de Kutch. Para isso, ofereceu sabões aos moradores desse local, ora por três rúpias, ora por 15 rúpias. Parte dos participantes era convidada a deliberar sobre a compra e os demais decidiam automaticamente. Como premissa da pesquisa, estava o conceito de um preço limítrofe subjetivo dos agentes: preços

73 VOHS, Kathleend.; FABER, RonaldJ. Spent resources: self-regulatory resource availability affects impulse buying.Journal of Consumer Research, [s.l.], v. 33, n. 4, p. 537-547, mar. 2007.

74 VOHS, Kathleen D.; HEATHERTON, Todd F. Self-regulatory failure: a resource-depletion approach.Psychological Science, [s.l.], v. 11 , n. 3, p. 249-254, maio 2000.

75 BAUMEISTER, Roy F. et al. Free will in consumer behavior: Self-control, ego depletion, and choice.Journal of Consumer Psychology, [s.l.], v. 18, n. 1, p. 4-13, jan. 2008. p. 10.

76 TIERNEY, John.Do you suffer from decision fatigue?. Disponível em: < https://www.nytimes.com/2011/08/21/magazine/do-yousuffer-from-decision-fatigue.html>.

77 MANKIW, N. Gregory. Introdução à economia. 3. ed. São Paulo: Cengage Learning, 2009. p. 6.

78 THALER, Richard.Misbehaving:the making of behavioral economics. Nova Iorque: W. W. Norton, 2016. p. 58.

79 MULLAINATHAN, Sendhil; SHAFIR, Eldar. Scarcity: why having too little means so much. Nova Iorque: Time Books, Henry Holt \& Company Llc, 2014.

80 SPEARS, Dean. Decision costs and price sensitivity: field experimental evidence from India.Journal Of Economic Behavior \& Organization, [s.1.], v. 97, p. 169-184, jan. 2014. Elsevier BV. Disponível em: <http://dx.doi.org/10.1016/j.jebo.2013.06.012>. 
superiores ao limite seriam rejeitados intuitivamente, mas poderiam ser aceitos se o agente fosse forçado a deliberar sobre a escolha. Para pessoas pobres, a condição de escassez faria com que esse limite fosse muito baixo e exigiria deliberação para ambos os valores colocados.

As premissas foram confirmadas. Segundo o autor ${ }^{81}$ :

[...] No grupo controle $84 \%$ compraram sabão quando ofertado por três rúpias e $29,8 \%$ compraram o sabão vendido por quinze rúpias. Entre os que deliberaram, $82,4 \%$ compraram o sabão por três rúpias e 39\% compraram o sabão por quinze.

[...] A situação de deliberação quase não teve efeito direto entre aqueles aos quais foi oferecido o sabão a três rúpias; [...]. Enquanto a situação de deliberação teve pouco efeito na venda a três rúpias, ela aumentou a aceitação em 10.7 pontos percentuais - ou mais de um terço - na venda a quinze rúpias, na qual o modelo sugere que as ofertas teriam sido ignoradas devido aos custos de deliberação.

Em que pese o benefício do sabão para aqueles indivíduos ${ }^{82}$ e, consequentemente, a expectativa de aquisição intuitiva, constatou-se que em situações próximas ao valor de mercado (15 rúpias ${ }^{83}$ ), a compra de sabão era rechaçada intuitivamente pelos indivíduos; contudo, a existência de deliberações aumentava a probabilidade de aquisição.

Deliberar, tal como narrado outrora, não é um processo gratuito. Considerando que transações relativamente simples já trazem custos cognitivos significativos em ambientes de pobreza extrema, é razoável esperar que outras decisões mais complexas, como as que envolvem o planejamento familiar, seriam ainda mais custosas e poderiam sequer atingir algum resultado. Os resultados do experimento acima não são isolados. Diversos outros experimentos comportamentais que serão abordados a seguir mostram a ampliação de vieses cognitivos em pessoas pobres, fato que pode levar ao autoreforço da própria situação de pobreza. Por isso, é possível dizer que há uma maior tributação cognitiva, nos termos de Mani et a ${ }^{\beta 4}$, sobre as pessoas mais pobres, como será melhor explanado na próxima seção.

Apresenta-se necessário, como antecedente da análise que se segue, o estabelecimento de três restrições metodológicas. A primeiro, de que a pobreza não é apenas a renda insuficiente: falhas das instituições, níveis de criminalidade, dificuldade de acesso a serviços básicos, como à saúde, e inúmeros outros obstáculos compõem esse conceito ${ }^{85}$; a segundo, não se sugere, com os questionamentos colocados neste trabalho, que os pobres seriam os culpados pela sua própria situação: inexistindo certas coincidências ambientais ${ }^{86}$, qualquer pessoa poderia estar nessas mesmas condições; a terceiro, apesar de não serem objeto de análise no presente artigo, abordagens de outros ramos do conhecimento, como a Sociologia e a Antropologia, não devem ser desconsideradas.

\subsection{A pobreza, os descontos intertemporais e a opção pelo caminho mais seguro}

As escolhas intertemporais e as escolhas em situações de risco são de extrema importância para os estudos econômicos. Conforme demonstrado anteriormente, parte da Economia Comportamental se dedicou

81 SPEARS, Dean. Decision costs and price sensitivity: field experimental evidence from India.Journal Of Economic Behavior \& Organization, [s.l.], v. 97, p. 169-184, jan. 2014. Elsevier BV. Disponível em: <http://dx.doi.org/10.1016/j.jebo.2013.06.012>. p. 180. Tradução nossa.

82 Conforme ressaltado por Spears (2014), o distrito de Kutch sofria com diarreia endêmica, que era ampliada pela falta de atos básicos de higiene, como lavar as mãos com sabão.

83 O valor de 15 rúpias, segundo cotações atuais, gira em torno de 83 centavos de real (https://pt.coinmill.com/BRL_INR. html\#INR=15). Conversão em 12 de maio de 2018.

84 MANI, A. et al. MANI, A. et al. Poverty impedes cognitive function. Science, [s.1.], v. 341, n. 6149, p. 976-980, 29 ago. 2013. American Association for the Advancement of Science (AAAS). Disponível em: <http://dx.doi.org/10.1126/science.1238041>. p. 980. 85 HAUSHOFER, J.; FEHR, E. On the psychology of poverty. Science, [s.l.], v. 344, n. 6186, p.862-867, 22 maio 2014. American Association for the Advancement of Science (AAAS). Disponível em: <http://dx.doi.org/10.1126/science.1232491>. p. 862.

86 HAUSHOFER, J.; FEHR, E. On the psychology of poverty. Science, [s.l.], v. 344, n. 6186, p.862-867, 22 maio 2014. American Association for the Advancement of Science (AAAS). Disponível em: < http://dx.doi.org/10.1126/science.1232491>. p. 862. 
a expor empiricamente desvios comportamentais nessas escolhas, em relação ao que previam os teoremas da economia tradicional.

Quanto às preferências intertemporais e escolhas sob risco de pessoas em situação de pobreza, o experimento realizado por Tanaka, Camerer e Nguyen ${ }^{87}$ apresenta-se pertinente. Nessa oportunidade, experimentos foram realizados com famílias vietnamitas de nove vilarejos, com diferenças substanciais nos níveis de renda média e de acesso ao mercado. Foram dadas instruções aos participantes que deveriam manter folhas de registro para cada jogo, com o fim de se avaliar posteriormente os níveis de desconto intertemporal e de aversão ao risco de cada participante ${ }^{88}$.

Os resultados dos autores são conclusivos:

Nossos resultados sugerem que a renda média do vilarejo é relacionada ao risco e às preferências temporais. Pessoas vivendo em vilarejos pobres não têm necessariamente medo da incerteza, no sentido de variação de renda; em vez disso, são avessas à perda. Quando introduzimos as variáveis instrumentais para a variáveis de renda, a renda média de um vilarejo é, também, significativamente correlacionada com aversão ao risco (concavidade da função de utilidade). Do experimento dos descontos no tempo, encontramos que a renda média de um vilarejo é correlacionada com menores taxas de desconto, isto é, pessoas vivendo em vilarejos mais ricos não só são menos avessas ao risco como também mais pacientes $^{89}$.

Além disso, conforme exposto por Haushofer e Fehr ${ }^{90}$, há resultados significativos de que: a) as taxas de desconto em famílias pobres nos Estados Unidos são maiores do que as de famílias ricas ${ }^{91}$; b) famílias agrícolas etíopes ${ }^{92}$ e amostras do sul da Índia ${ }^{93}$ apontam para descontos mais elevados em famílias de rendas mais baixas; c) famílias mais ricas apresentam níveis mais baixos de aversão ao risco ${ }^{94}$.

Esses resultados expõem situações que podem ser perniciosas, na medida em que parecem ser capazes de reforçar a própria condição de pobreza. Isso porque, enquanto indivíduos mais ricos conseguiriam poupar mais para o futuro e assumir pequenos riscos a fim de obter resultados econômicos satisfatórios, a situação de pobreza poderia fazer com que os riscos fossem superestimados e com que o presente fosse privilegiado, em detrimento do futuro.

Ilustra esse potencial ciclo vicioso o trabalho de Shah, Mullainathan e Shafir ${ }^{96}$, no qual se constata a pre-

87 TANAKA, Tomomi; CAMERER, Colin F; NGUYEN, Quang. Risk and time preferences: linking experimental and household survey data from Vietnam. American Economic Review, [s.1.], v. 100, n. 1, p. 557-571, mar. 2010. American Economic Association. Disponível em: <http://dx.doi.org/10.1257/aer.100.1.557>.

88 TANAKA, Tomomi; CAMERER, Colin F; NGUYEN, Quang. Risk and time preferences: linking experimental and household survey data from Vietnam. American Economic Review, [s.l.], v. 100, n. 1, p. 557-571, mar. 2010. American Economic Association. Disponível em: <http://dx.doi.org/10.1257/aer.100.1.557>. p. 559.

89 TANAKA, Tomomi; CAMERER, Colin F; NGUYEN, Quang. Risk and time preferences: linking experimental and household survey data from Vietnam. American Economic Review, [s.1.], v. 100, n. 1, p. 557-571, mar. 2010. American Economic Association. Disponível em: <http://dx.doi.org/10.1257/aer.100.1.557>. p. 569. Tradução nossa.

90 HAUSHOFER, J.; FEHR, E. On the psychology of poverty. Science, [s.l.], v. 344, n. 6186, p.862-867, 22 maio 2014. American Association for the Advancement of Science (AAAS). Disponível em: < http://dx.doi.org/10.1126/science.1232491>. p. 862.

91 LAWRANCE, Emily C. Poverty and the rate of time preference: evidence from panel data.Journal of Political Economy, [s.l.], v. 99, n. 1, p. 54-77, fev. 1991. University of Chicago Press. Disponível em: <http://dx.doi.org/10.1086/261740>.

92 YESUF, Mahmud; BLUFFSTONE, Randall. Wealth and time preference in rural ethiopia.Environment For Development, [s.1.], v. 16, n. 08, p. 1-18, jun. 2008. Disponível em: <http://www.rff.org/files/sharepoint/WorkImages/Download/EfD-DP-08-16.pdf>. 93 PENDER, John L. Discount rates and credit markets: theory and evidence from rural india.Journal Of Development Economics, [s.l.], v. 50, n. 2, p. 257-296, ago. 1996. Elsevier BV. Disponível em: <http://dx.doi.org/10.1016/s0304-3878(96)00400-2>.

94 DOHMEN, Thomas et al. Individual risk attitudes: measurement, determinants, and behavioral consequences.Journal of The European Economic Association, [s.l.], v. 9, n. 3, p. 522-550, 31 mar. 2011. Oxford University Press (OUP). Disponível em: < http:// dx.doi.org/10.1111/j.1542-4774.2011.01015.x>.

95 GUISO, Luigi; PAIELLA, Monica. Risk aversion, wealth, and background risk. Journal of The European Economic Association, [s.l.], v. 6, n. 6, p. 1109-1150, dez. 2008. Oxford University Press (OUP). Disponível em: < http://dx.doi.org/10.1162/jeea.2008.6.6.1109>. 96 SHAH, A. K.; MULLAINATHAN, S.; SHAFIR, E. Some consequences of having too little. Science, [s.1.], v. 338, n. 6107, p. 682-685, nov. 2012. American Association for the Advancement of Science (AAAS). Disponível em: <http://dx.doi.org/10.1126/ science.1222426>. 
valência de comportamentos econômicos danosos a longo prazo, como por exemplo, a baixa poupança, o excesso de empréstimos, muitas vezes com taxas de juros elevadas, o alto percentual de indivíduos pobres que jogam em loterias ${ }^{97}$ e as falhas para se inscrever em programas assistenciais.

O gráfico a seguir, por exemplo, demonstra a evolução da taxa de poupança nos EUA entre diferentes classes sociais e expõe como as pessoas mais pobres tendem a poupar menos, se comparadas às mais ricas:

Figura 1 - Taxa de poupança de acordo com faixas de renda (médias decenais)

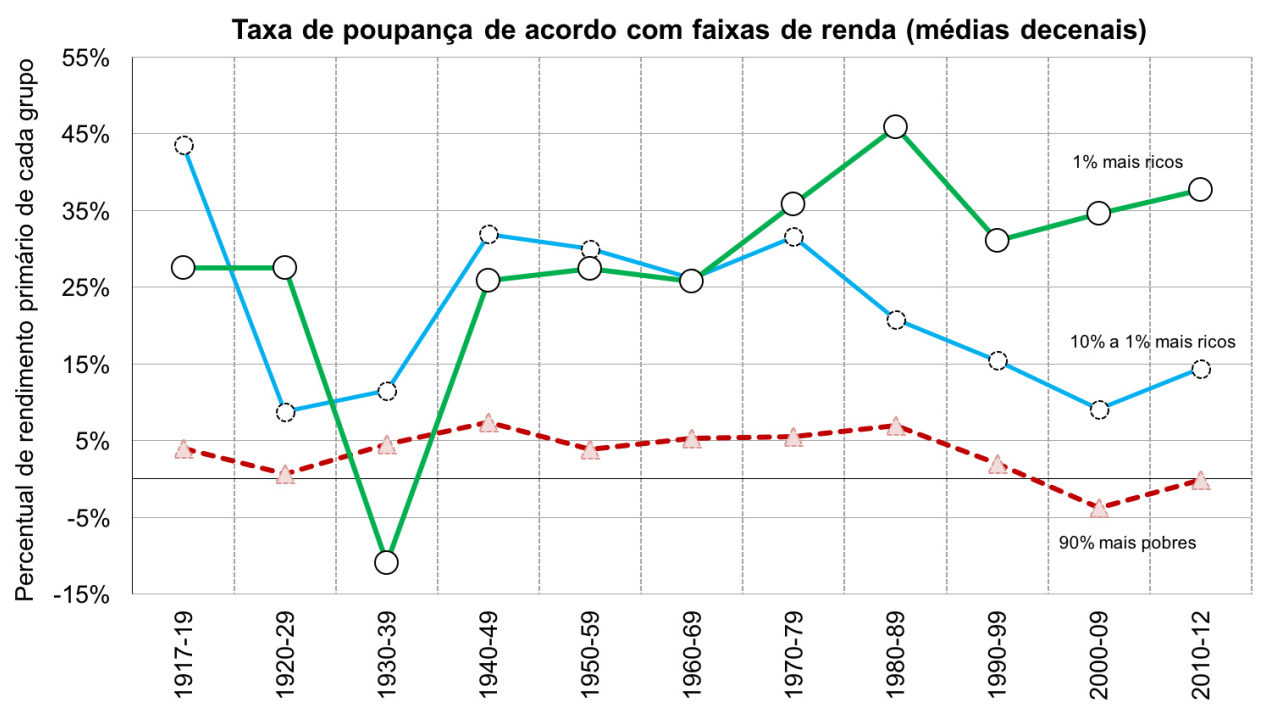

Fonte: Elaboração própria. Fonte: SAEZ, Emmanuel; ZUCMAN, Gabriel. Wealth inequality in the united states since 1913: evidence from capitalized income tax data.National Bureau Of Economic Research, Cambridge, Ma, p. 1-46, out. 2014. Disponível em: <http://dx.doi.org/10.3386/w20625>. Dados adicionais em: <http://gabriel-zucman.eu/files/SaezZucman2015MainData.xlsx>.

Como já ressaltado, todas as escolhas envolvem custos cognitivos. Tendo em vista que mesmo escolhas simples, por exemplo, a compra do sabão do já citado experimento de Spears ${ }^{98}$, são consideravelmente custosas cognitivamente para sujeitos em escassez extrema, é possível dizer que, sobre tais indivíduos, incide uma maior tributação cognitiva, se comparada aos indivíduos mais ricos ${ }^{99}$.

Tal metáfora é extremamente oportuna para ilustrar todo o quadro exposto das decisões econômicas em situação de pobreza. A imposição de alguns tributos - por exemplo, impostos sobre o consumo - pode, como efeito secundário indesejado, ter o condão de reduzir a mobilidade social de uma determinada sociedade. Mantém-se, assim, os níveis de desigualdade social existentes. Diz-se ser regressivos os tributos que possuem esse caráter, em oposição aos tributos progressivos que, em respeito ao princípio da capacidade contributiva, almejam reduzir as desigualdades existentes.

Como ressaltado, as decisões econômicas de pessoas mais pobres são muito mais custosas do que as decisões de pessoas mais ricas. Isso faz com que alguns vieses sejam vistos com maior frequência em situação de pobreza. Por exemplo, descontos intertemporais mais excessivos e maior aversão ao risco. Por conta disso, os resultados econômicos de pessoas mais pobres podem acabar sendo piores, especialmente a longo prazo, que o de pessoas mais ricas. Isso fica bastante evidente quando são analisados os níveis de poupança,

97 Frise-se que tal fato não contradiz a afirmação de que a pobreza implica em uma maior aversão ao risco. Tal assertiva deve ser lida em consonância com o padrão quádruplo. Assim, a interpretação mais adequada parecer ser a de que, em que pese na maior das situações tais indivíduos serem avessos ao risco, há casos, como nas loterias, em que buscam sobremaneira o risco. 98 SPEARS, Dean. Decision costs and price sensitivity: field experimental evidence from India.Journal Of Economic Behavior \& Organization, [s.l.], v. 97, p. 169-184, jan. 2014. Elsevier BV. Disponível em: <http://dx.doi.org/10.1016/j.jebo.2013.06.012>.

99 MANI, A. et al. Poverty impedes cognitive function. Science, [s.1.], v. 341, n. 6149, p. 976-980, 29 ago. 2013. American Association for the Advancement of Science (AAAS). Disponível em: <http://dx.doi.org/10.1126/science.1238041>. p. 980. 
o excesso de empréstimos, o endividamento excessivo e, mesmo, padrões de investimentos com menores riscos, mas também menos rentáveis.

A potencial regressividade de tal tributação ${ }^{100}$ resta evidente quando se percebe que, ao atingir piores resultados econômicos, a própria condição de pobreza é reforçada. Sendo assim, os trade-offs passam a ser ainda mais intensos e, com menos recursos, as decisões ainda mais custosas. Daí a ideia de "tributação cognitiva". Como a tributação propriamente dita, a cognitiva impõe um fardo maior aos indivíduos mais pobres, por conta de os custos cognitivos de decisões idênticas serem muito significativos para eles em comparação com os que ocupam os estratos sociais superiores.

Dada a potencial regressividade de tal tributação, os formuladores de políticas públicas devem estar atentos aos custos cognitivos que são excessivamente impostos aos mais pobres e, com isso, tentar simplificar as suas escolhas. Conforme será demonstrado na seção 4, muitas decisões são excessivamente complexas e trazem custos cognitivos ainda mais intensos para as pessoas em situação de pobreza. Isso porque, nesses casos, há chances enormes de que escolhas inadequadas sejam feitas ou, até mesmo, que o resultado seja o de ausência de escolhas. Simplificar e tornar mais fáceis escolhas como as relativas a poupanças, contratos bancários, planos de previdência etc. pode ser uma forma de combater esses efeitos cognitivamente adversos da pobreza.

Diversas causas são atribuídas para esses problemas. O esgotamento do ego atingido mais rápida e intensamente ${ }^{101}$, prejuízos às funções $\operatorname{cognitivas~}^{102}$, maiores níveis de stress ${ }^{103}$ e a atenção voltada para a escassez são indicados como causas potenciais ${ }^{104}$. A abordagem detalhada de todas essas questões será feita na próxima subseção.

\subsection{Pobreza, esgotamento e funções cognitivas: uma abordagem holística necessária}

Como ressaltado, existem custos cognitivos acentuados relacionados à escassez ${ }^{105}$, o que faz com que as pessoas mais pobres tenham, normalmente, o aprofundamento de alguns vieses comportamentais. Especificamente, trabalhou-se, até aqui, com descontos intertemporais mais acentuados e o excesso de aversão ao risco.

Diversas teorias se propõem a expor as minúcias da relação entre pobreza e comportamento. A primeira delas tem seu fulcro no conceito de escassez ${ }^{106}$. Como a atenção é limitada, os humanos direcionam o seu foco atencional para o que lhes é mais urgente. A pobreza financeira tende a ocupar excessivamente a atenção de uma pessoa, o que reduz o seu desempenho em decisões importantes e em comportamentos $\operatorname{cotidianos}^{107}$.

100 Ressalta-se, novamente, não se estar diante da tributação propriamente dita, isto é, da cobrança de tributos. Trata-se, na verdade, de uma oportuna metáfora para os padrões decisórios - e os seus resultados - encontrados em situação de pobreza.

101 SPEARS, Dean. Economic decision-making in poverty depletes behavioral control.The B.e. Journal of Economic Analysis \& Policy, [s.l], v. 11, n. 1, p. 1-42, 2011. Disponível em: <http://lisagennetian.org/files/92920599.pdf>.

102 MANI, A. et al. Poverty impedes cognitive function. Science, [s.l.], v. 341, n. 6149, p. 976-980, 29 ago. 2013. American Association for the Advancement of Science (AAAS). Disponível em: <http://dx.doi.org/10.1126/science.1238041>.

103 HAUSHOFER, J.; FEHR, E. On the psychology of poverty. Science, [s.l.], v. 344, n. 6186, p.862-867, 22 maio 2014. American Association for the Advancement of Science (AAAS). Disponível em: <http://dx.doi.org/10.1126/science.1232491>.

104 SHAH, A. K.; MULLAINATHAN, S.; SHAFIR, E. Some consequences of having too little. Science, [s.l.], v. 338, n. 6107, p. 682-685, nov. 2012. American Association for the Advancement of Science (AAAS). Disponível em: <http://dx.doi.org/10.1126/ science.1222426>.

105 O termo escassez adquire a conotação similar àquela presente do termo "pouco" - não se confundindo, portanto, com o conceito econômico associado à ideia de "limitado".

106 SHAH, A. K.; MULLAINATHAN, S.; SHAFIR, E. Some consequences of having too little. Science, [s.l.], v. 338, n. 6107, p. 682-685, nov. 2012. American Association for the Advancement of Science (AAAS). Disponível em: <http://dx.doi.org/10.1126/ science.1222426>.

107 SPEARS, Dean. Economic decision-making in poverty depletes behavioral control.The B.e. Journal of Economic Analysis \& Policy, [s.l], v. 11, n. 1, p. 1-42, 2011. Disponível em: <http://lisagennetian.org/files/92920599.pdf>. p. 5. 
A segunda teoria baseia-se na noção de controle cognitivo, que pode ser entendido como um processo que direciona a atenção ou inibe comportamentos em prol de alguma meta ${ }^{108}$. Mani et al. ${ }^{109}$ demonstraram experimentalmente a diminuição das funções cognitivas em períodos de grande pressão econômica. Para isso, aferiram os indicadores relacionados às funções cognitivas de plantadores de cana de açúcar nos períodos pré e pós-colheita. Digna de nota a pressão financeira dos participantes: antes das colheitas, há maior escassez de recursos e maior incerteza quanto aos resultados da próxima safra, em comparação com o período após a colheita. A diminuição das funções cognitivas dos agricultores nesse período de maior pressão financeira é equivalente à que ocorreria com a privação de aproximadamente uma noite de sono.

Além disso, há autores que afirmam que os padrões comportamentais já expostos encontrados na situação de pobreza seriam provocados pelo aumento do stress e do afeto negativo ${ }^{110}$. Haushofer e Fehr constataram experimentalmente que o aumento dos níveis de cortisol e a tristeza podem ser capazes de ampliar a aversão ao risco e de acentuar os descontos intertemporais.

Por fim, a última teoria que se propõe a expor as minúcias da relação entre pobreza e comportamento se baseia na teoria do esgotamento do ego - já exposta na subseção 2.3. Como já ressaltado, a força de vontade é limitada e o controle do comportamento consome tais reservas mentais. Decisões em situação de pobreza implicam em trade-offs mais intensos ligados à escassez, sendo capazes de causar mais rapidamente o esgotamento do ego. Vale lembrar que, no experimento de Spears ${ }^{111}$, a deliberação era exigida para realizar uma transação simples, como comprar um sabão.

A fim de testar essa hipótese, em novo experimento conduzido por Spears, pessoas eram levadas a escolher entre três produtos, quais sejam, uma lata de óleo de cozinha, uma marmita de metal e um pacote de cordas ${ }^{112}$. Dois grupos diferentes foram aleatoriamente separados: um com recursos suficientes para escolher todos os itens mais desejados (óleo e marmita) e o outro que deveria enfrentar um trade-off entre os produtos a serem escolhidos. Os participantes, habitantes de Banswara, na zona rural da Índia, de fato receberiam os produtos escolhidos ao fim do experimento.

Feita a escolha econômica, Spears mediu o autocontrole desses indivíduos ao realizarem uma tarefa simples: apertar um exercitador do tipo handgrip. O pesquisador verificou que as pessoas que se encontravam na condição de maior escassez apertavam o aparelho por menos tempo, apresentando sinais de ocorrência de esgotamento do ego.

O pesquisador, então, conclui ${ }^{113}$ :

Finalmente, descobrir que o efeito da pobreza no controle comportamental depende de reservas pessoais de algum dos recursos hipoteticamente abordados - atenção, força de vontade ou controle cognitivo sugeriria que o esgotamento desses recursos é um mecanismo importante. Os estudos abaixo podem ser sugestivos entre essas distinções, mas sua implicação mais importante é que alguma combinação desses três mecanismos similares importa para o controle comportamental do pobre.

É imprescindível trazer a constatação de que o esgotamento do ego ocorre em diversas situações com qualquer pessoa. Pessoas ricas também lidam com dificuldades de autocontrole, ligadas a recursos mentais

108 SPEARS, Dean. Economic decision-making in poverty depletes behavioral control.The B.e. Journal of Economic Analysis \& Policy, [s.l], v. 11, n. 1, p. 1-42, 2011. Disponível em: <http://lisagennetian.org/files/92920599.pdf>. p. 5.

109 MANI, A. et al. Poverty impedes cognitive function. Science, [s.l.], v. 341, n. 6149, p. 976-980, 29 ago. 2013. American Association for the Advancement of Science (AAAS). Disponível em: < http://dx.doi.org/10.1126/science.1238041>.

110 HAUSHOFER, J.; FEHR, E. On the psychology of poverty. Science, [s.l.], v. 344, n. 6186, p.862-867, 22 maio 2014. American Association for the Advancement of Science (AAAS). Disponível em: <http://dx.doi.org/10.1126/science.1232491>.

111 SPEARS, Dean. Decision costs and price sensitivity: field experimental evidence from India.Journal Of Economic Behavior \& Organization, [s.1.], v. 97, p. 169-184, jan. 2014. Elsevier BV. Disponível em: <http://dx.doi.org/10.1016/j.jebo.2013.06.012>.

112 SPEARS, Dean. Economic decision-making in poverty depletes behavioral control.The B.e. Journal of Economic Analysis \& Policy, [s.l], v. 11, n. 1, p. 1-42, 2011. Disponível em: <http://lisagennetian.org/files/92920599.pdf>.

113 SPEARS, Dean. Economic decision-making in poverty depletes behavioral control.The B.e. Journal of Economic Analysis \& Policy, [s.l], v. 11, n. 1, p. 1-42, 2011. Disponível em: <http://lisagennetian.org/files/92920599.pdf>. Tradução nossa. 
finitos. Porém, o foco do presente trabalho é evidenciar que a pobreza pode ampliar esses efeitos de esgotamento e, assim, provocar vieses comportamentais mais acentuados.

Não há exclusão de abordagens diversas. Todas as teorias aqui expostas são complementares. Como as pessoas focam a sua atenção -limitada - naquilo que é escasso, o esgotamento do ego acontece de maneira mais rápida, na medida em que as escolhas são mais difíceis. Isso também explica a diminuição das funções cognitivas, que retrata esse efeito em um nível explicativo diferente. Ao cabo, todo o processo pode levar a maiores níveis de stress e ao afeto negativo, que também prejudicam as decisões ${ }^{114}$.

\section{REDUZINDO A TRIBUTAÇÃO COGNITIVA: A OPÇÃO PELOS NUDGES}

Ao longo de todo este trabalho, apontou-se que as consequências psicológicas de possuir poucos recursos financeiros prejudicam a tomada de decisões. Dessa maneira, há maiores custos decisórios para as pessoas mais pobres, o que torna piores os seus resultados econômicos. Cria-se, então, uma situação análoga a uma tributação cognitiva, que pode ter graves efeitos regressivos, no sentido de reforçar a própria situação de pobreza.

Nesse quadro, podem ser formuladas políticas públicas para atuar de três maneiras distintas, como expõe Haushofer e Fehr ${ }^{115}$ :

Finalmente, quais tipos de programas de bem-estar ou intervenções iriam quebrar os relacionamentos discutidos acima? Se o feedback loop proposto for verdadeiro, três possibilidades parecem promissoras para quebrar o ciclo e melhorar o bem-estar: A primeira é enfrentar a pobreza diretamente, a segunda é enfrentar as suas consequências psicológicas, e a terceira é enfrentar os comportamentos econômicos que resultam delas. Essas possibilidades não são mutualmente exclusivas, é claro, mas devem ser estudadas isoladamente assim como combinadas para o entendimento dos seus efeitos.

Neste trabalho, serão analisadas, especificamente, as possibilidades de intervenções que atuam para atenuar os prejuízos gerados por decisões econômicas inadequadas feitas em situação de escassez. Não se descarta, por óbvio, a enorme importância de se enfrentar diretamente a pobreza, bem como de se enfrentar as suas consequências psicológicas, por exemplo, por meio, respectivamente, de políticas redistributivas e de políticas relacionadas à psicoterapias.

A fim de elaborar políticas públicas que enfrentem os prejuízos decisórios provocados pelas consequências psicológicas da pobreza, opta-se, aqui, pelo método dos nudges, tal como proposto por Thaler e Sunstein ${ }^{116}$.

Um nudge, nessa perspectiva, seria:

[...] qualquer aspecto da arquitetura de escolhas que altere o comportamento das pessoas de uma maneira previsível sem proibir quaisquer opções ou modificar significativamente os seus incentivos econômicos. Para contar como um mero nudge, a intervenção deve ser simples e fácil de se evitar. Nudges não são mandados. Colocar a fruta no nível do olho é considerado um nudge. Banir comidas não-saudáveis, não. ${ }^{117}$

114 Importante ressaltar que não é o objetivo deste trabalho expor empiricamente todas essas correlações. Aponta-se, apenas, a relação entre o comportamento e a pobreza como uma importante agenda de estudos a serem desenvolvidos para a comprovação dessas hipóteses.

115 HAUSHOFER, J.; FEHR, E. On the psychology of poverty. Science, [s.l.], v. 344, n. 6186, p.862-867, 22 maio 2014. American Association for the Advancement of Science (AAAS). Disponível em: <http://dx.doi.org/10.1126/science.1232491>. p. 866. 116 THALER, Richard H.; SUNSTEIN, Cass R.Nudge:improving decisions about health, wealth and happiness. Londres: Penguin Books, 2009.

117 THALER, Richard H.; SUNSTEIN, Cass R.Nudge:improving decisions about health, wealth and happiness. Londres: Penguin Books, 2009. p. 6. Tradução nossa. 
A opção pelos nudges se mostra pertinente na medida em que não tolhe as opções de escolha dos agentes econômicos, mas ao mesmo tempo, considera as suas limitações e direciona o rumo de suas decisões. Assim, nudges esperam o erro, simplificam escolhas muito complexas, fornecem feedbacks rápidos e criam padrões (defaults) para as situações em que o sujeito pode permanecer inerte e não realizar escolha alguma. Em suma, nudges são políticas públicas voltadas para humanos, que não estruturam os seus incentivos como esperado pela teoria econômica tradicional, que se pauta no modelo do Homo Economicus ${ }^{118}$.

Brevemente, apresenta-se válido tratar acerca de algumas modalidades de incentivos que podem ser consideradas nudges. A inscrição automática em programas governamentais, por exemplo, voltados para a poupança, é um nudge, que se pauta pela criação ou alteração de regras default $t^{19}$. O programa Save More Tomorrow, idealizado por Thaler e Benartzi ${ }^{120}$, é um exemplo clássico de nudge que obteve êxito ao aumentar consideravelmente os níveis de poupança para a aposentadoria.

Outra modalidade importante é o uso de normas sociais. A esse respeito, Sunstein ${ }^{121}$ aponta:

Um dos nudges mais eficazes consiste em informar às pessoas que a maioria das outras apresenta determinado comportamento. Essa informação frequentemente é tanto mais eficaz quanto mais ela for específica e ligada a uma determinada localidade ("a esmagadora maioria das pessoas da sua comunidade paga seus impostos em dia"). O uso de normas sociais pode reduzir o comportamento criminoso e também comportamentos que sejam prejudiciais, criminosos ou não (como abuso de álcool, tabagismo e discriminação).

Especificamente em relação às regras default, pode-se dizer que elas são inevitáveis. Qualquer política pública traz consigo um padrão para os resultados trazidos pela omissão do agente. Por exemplo, no caso das doações de órgãos, o sujeito se manter inerte pode significar tanto que ele é um doador (consentimento presumido - opt out) ou que ele não é um doador (consentimento explícito - opt in). Comum a qualquer default é a possibilidade de o sujeito modificar a sua situação ao se portar ativamente.

Como já restou demonstrado ao longo de todo trabalho, escolher é custoso cognitivamente e isso se acentua para as pessoas mais pobres. Por conta disso, é possível dizer, metaforicamente, que incide uma maior tributação cognitiva sobre as pessoas mais pobres, que leva-as a piores resultados econômicos e que tende a reforçar a própria situação de pobreza. Regras default, nesse sentido, podem ter o condão de tornar algumas escolhas desnecessárias, trazendo mais liberdade e mais qualidade para a vida dos agentes ${ }^{122}$. Isso se mostra especialmente válido nas situações em que: (i) o contexto é confuso, técnico e desconhecido; (ii) as pessoas iriam preferir não escolher; (iii) aprender não é importante para o agente, e (iv) a população não é heterogênea em qualquer dimensão relevante ${ }^{123}$.

Qualquer política pública envolve a formulação de sua arquitetura de escolhas, ou seja, do contexto no qual as pessoas vão tomar decisões ${ }^{124}$. Os arquitetos de escolha, responsáveis por organizar esse contexto,

118 Ultrapassa os objetivos desse artigo discorrer longamente sobre os nudges, tendo em vista a sua vasta utilização ao redor do planeta. Diversos países criaram centros de análise de políticas públicas para aplicar a Economia Comportamental, tendo por base, principalmente, os nudges. São as chamadas Nudge Units. Para um panorama geral acerca das principais políticas já adotadas nessas unidades, ver: OECD (2017),Behavioural Insights and Public Policy:Lessons from Around the World, OECD Publishing, Paris. http://dx.doi.org/10.1787/9789264270480-en.

119 SUNSTEIN, Cass R. Nudging: um guia bem breve. In: ÁVILA, Flávia; BIANCHI, Ana Maria. Guia de Economia Comportmental e Experimental. São Paulo: Economiacomportamental.org, 2015. p. 109-114. p. 111.

120 THALER, Richard H.; BENARTZI, Shlomo. Save more tomorrow ${ }^{\text {TM}}$ : using behavioral economics to increase employee saving. Journal Of Political Economy, [s.l.], v. 112, n. 1, p. 164-187, fev. 2004. University of Chicago Press. Disponível em: <http://dx.doi. org/10.1086/380085>.

121 SUNSTEIN, Cass R. Nudging: um guia bem breve. In: ÁVILA, Flávia; BIANCHI, Ana Maria. Guia de Economia Comportmental e Experimental. São Paulo: Economiacomportamental.org, 2015. p. 109-114. p. 112.

122 SUNSTEIN, Cass R. Choosing not to choose: understanding the value of choice. New York: Oxford University Press, 2015. p. $14-15$.

123 SUNSTEIN, Cass R. Choosing not to choose: understanding the value of choice. New York: Oxford University Press, 2015. p. 18. 124 THALER, Richard H.; SUNSTEIN, Cass R.Nudge:improving decisions about health, wealth and happiness. Londres: Penguin Books, 2009. p. 3. 
sempre trabalham com incentivos ao elaborar suas políticas. Como ressalta Thaler e Sunstein, um ponto de partida oportuno ao pensar sobre arquitetura de escolhas em particular é delimitar, de imediato, qual é o público-alvo, quem fará as escolhas, quem são os financiadores e quem lucrará com o sistema desenvolvido. ${ }^{125}$

Todo o exposto no presente trabalho mostra que as decisões econômicas de pessoas em condição de pobreza são prejudicadas. Há maior aversão ao risco e maiores descontos intertemporais. Pode-se dizer, ainda, que há uma menor capacidade de autocontrole, relacionada a esgotamento do ego intensificado. Por conta disso, o arquiteto de escolhas, ao formular políticas que tenham como destinatários pessoas em situação de escassez extrema, deve ter ciência desses padrões comportamentais e de como eles impactarão o resultado de sua política.

Ainda que diversos programas sociais sejam criados com o fim de lutar contra a pobreza, muitas vezes a análise dos seus resultados não é voltada para a arquitetura de escolhas existente na própria política - e eventuais fracassos são vistos como a ausência de entendimento ou de motivação dos destinatários da política pública. Note-se que, por vezes, o debate político raso é permeado por ideias calcadas no mérito, que afirmam, por exemplo, que a situação de pobreza é um reflexo da falta de vontade de ascensão social do próprio indivíduo.

Geralmente, as políticas públicas não são desenhadas de forma a esperar o erro dos seus destinatários, que, em se tratando de situação de pobreza, tende a ser mais frequente ${ }^{126}$ : como já ressaltado, a pobreza favorece comportamentos avessos ao risco, enviesados para o presente e diminui as capacidades mentais relacionadas ao autocontrole. Não pode, assim, o formulador de políticas públicas abster-se de esperar falhas em seu projeto, porquanto a situação de seu público-alvo por vezes favorece comportamentos transviados. Em outras palavras, deve o gestor esforçar-se para atenuar a tributação cognitiva, isto é, as políticas públicas devem almejar retirar parte do fardo existente sobre as pessoas mais pobres, de modo a tentar aprimorar o resultado de suas decisões.

Além disso, muitas vezes os programas sociais trazem consigo incentivos ineficazes. Note-se, por exemplo, o Programa de Assistência Temporária para Famílias Necessitadas (Temporary Assistance for Needy Families), do governo estadunidense, no qual se impunha um limite temporal de cinco anos, distribuídos ao longo de toda a vida do beneficiário, para a concessão de benefícios ${ }^{127}$. Isso ignora as dificuldades humanas de lidar com eventos futuros e as falhas de autocontrole ligadas à procrastinação, vieses tais que são agravados com a situação pobreza. Uma alternativa mais adequada, conforme explicam Mullainathan e Shafir ${ }^{128}$, seria a criação de prazos menores e mais frequentes, distribuídos conforme a necessidade do agente, e acompanhados de lembretes acerca dos limites existentes.

A preocupação em desenhar políticas públicas que esperem erros e que criem incentivos eficazes é justificada por conta de os humanos possuírem uma capacidade mental (mental bandwidth) limitada - motivo pelo qual nem todas as informações são processadas conscientemente e a maior parte das decisões é feita de maneira intuitiva.

$\mathrm{Na}$ condição de maior escassez, os trade-offs mais intensos aos quais essas pessoas estão submetidas ocupam boa parte dessa capacidade. Por isso, qualquer situação que exige do sujeito escolhas ativas deve ter ciência de que está consumindo parte dessa capacidade. Deve, ainda, ter noção que as pessoas mais ricas possuem maior capacidade mental (mental bandwidth) disponível - por não estarem tão pressionadas -, fato

125 THALER, Richard H.; SUNSTEIN, Cass R.Nudge:improving decisions about health, wealth and happiness. Londres: Penguin Books, 2009. p. 99.

126 MULLAINATHAN, Sendhil; SHAFIR, Eldar. Scarcity: why having too little means so much. Nova Iorque: Time Books, Henry Holt \& Company Llc, 2014. p. 250.

127 MULLAINATHAN, Sendhil; SHAFIR, Eldar. Scarcity: why having too little means so much. Nova Iorque: Time Books, Henry Holt \& Company Llc, 2014. p. 252.

128 MULLAINATHAN, Sendhil; SHAFIR, Eldar. Scarcity: why having too little means so much. Nova Iorque: Time Books, Henry Holt \& Company Llc, 2014. p. 253. 
que pode trazer elementos regressivos para a política elaborada. De outra maneira: qualquer política - em qualquer de suas fases - deve esperar identificar os elementos que traduzem a tributação cognitiva. Nessas circunstâncias, políticas que, muitas vezes, aparentam ter resultados modestos, podem, na verdade, produzir grandes mudanças na vida de um indivíduo, ao otimizar a utilização de seus recursos mentais ${ }^{129}$. Mullainathan e Shafir ${ }^{130}$ dizem que políticas públicas podem construir essa capacidade mental e exemplificam tal situação da seguinte maneira:

Você é uma mãe solteira que possui dois empregos. Você tem que se desdobrar. Para além dos malabarismos financeiros sobre os quais já discutimos, você tem que se desdobrar para o cuidado diário de suas crianças, que é caro. Você conhece um programa que é altamente subsidiado, mas que somente aceitará uma de suas crianças e fecha muito cedo para ajudar com o seu segundo emprego. Então você utiliza uma colcha de retalhos de soluções. Você deixa o seu filho mais novo com a sua avó. Você consegue transporte da escola para a casa de sua avó para uma das crianças e para a creche para a outra. E como você trabalha no setor de serviços, as necessidades de suas crianças dependem das horas que a sua supervisora lhe fornece. Ela é legal e tenta ajudar, mas há uma volatilidade inevitável.

Agora imagine que oferecemos a você um programa extremamente subsidiado de creches. O que exatamente você está ganhando com isso? Certamente, está poupando o seu tempo levando as crianças para lá e para cá. Nós talvez estaremos também poupando o seu dinheiro, tanto explicitamente (esse programa é mais barato que o anterior) quanto implicitamente (se contarmos com o tempo de sua avó). Mas o que estaríamos dando para você é algo diferente, ainda mais precioso. Algo que você poderia gastar em várias coisas. Nós devolveríamos toda a capacidade mental que você usa atualmente para se afligir, se preocupar e desdobrar todos esses arranjos. Nós retiraríamos uma carga cognitiva. Como vimos, isso ajudaria o seu controle executivo, o seu autocontrole de maneira mais ampla, até mesmo a criação de seus filhos. Isso melhoraria a sua capacidade cognitiva, a sua habilidade de focar, a qualidade do seu trabalho ou qualquer outra coisa para a qual você direcionar a sua mente.

O uso de nudges já possui sólida aplicação internacional. Como exemplo disso, serão expostas duas políticas públicas que obtiveram êxito ao se basear em aspectos comportamentais. Como será demonstrado, a consideração de tais aspectos, à época de se formular uma política pública, promove um ciclo virtuoso de resultados, hábeis a reduzir os danos potenciais da tributação cognitiva e, assim, contribuir para a redução das desigualdades.

A primeira intervenção profícua originou-se no Reino Unido, e foi realizada pelo Behavioral Insights Team junto com o Department for Business, Innovation and Skills ${ }^{131}$. Tinha como objetivo a ampliar as taxas de frequência e diminuir os índices de evasão após as férias escolares, em turmas de educação para adultos. Para isso, enviavam lembretes por SMS para os participantes que tinham baixo desempenho em matemática e língua inglesa, encorajando-os a persistir e introjetando ideias como a importância do estudo e da prática para o sucesso. O resultado foi um aumento de 7\% nas frequências e uma diminuição de 36\% na evasão após as férias. Esse é um claro exemplo de política pública que sabe ter como destinatários humanos que erram previsivelmente, sobretudo se submetidos a condições de pobreza.

A segunda intervenção foi realizada pela instituição financeira dominicana ADOPEM, cuja carteira de clientes se resume a pequenos empresários, como donos de mercearias, de salões de beleza e de lanchonetes ${ }^{132}$. O banco constatou que seus clientes cometiam erros frequentes em seus livros de registro, e decidiu intervir através da educação financeira.

129 MULLAINATHAN, Sendhil; SHAFIR, Eldar. Scarcity: why having too little means so much. Nova Iorque: Time Books, Henry Holt \& Company Llc, 2014. p. 260.

130 MULLAINATHAN, Sendhil; SHAFIR, Eldar. Scarcity: why having too little means so much. Nova Iorque: Time Books, Henry Holt \& Company Llc, 2014. p. 259.

131 OECD.Behavioural insights and public policy:lessons from around the world, OECD Publishing, Paris,Disponível em: <http:// dx.doi.org/10.1787/9789264270480-en>. p. 102-104.

132 DREXLER, Alejandro; FISCHER, Greg; SCHOAR, Antoinette. Keeping it simple: financial literacy and rules of thumb. American Economic Journal: Applied Economics, [s.l.], v. 6, n. 2, p. 1-31, abr. 2014. American Economic Association. Disponível em: $<$ http://dx.doi.org/10.1257/app.6.2.1>. 
Os próprios autores, economistas, encontraram dificuldades para compreender os manuais de contabilidade que eram disponibilizados para seu público-alvo. Assim, em vez de se basearem nesses materiais, analisaram como os pequenos empresários mais bem sucedidos se comportavam e verificaram que eles utilizavam inúmeras "regras de bolso" (rules of thumb) para facilitar o seu cotidiano financeiro. Essas regras se relacionavam com métodos de contabilidade mental, por exemplo, separar em diferentes potes o dinheiro que o negócio estava rendendo do "dinheiro da casa". Diante disso, criaram aulas de educação financeira baseadas nessas "regras de bolso".

Verificou-se que, além da maiores frequência e absorção de conhecimento por parte dos discentes, a receita média dos pequenos empresários cresceu cerca de $25 \%$ especialmente nas semanas ruins, em que a organização financeira apresenta-se mais decisiva.

Os dois exemplos acima citados mostram os efeitos positivos que uma política bem informada acerca dos vieses comportamentais, especialmente aqueles que são identificados excessivamente em pessoas mais pobres, podem atingir. Ademais, são ilustrativos de como uma boa política pode ter o condão de reduzir a tributação cognitiva. Aumentar as habilidades de inglês e de matemática de pessoas adultas, sem maiores custos cognitivos para elas, pode ajudar a romper com uma situação que contribuiria para autoreforçar a pobreza. O mesmo pode ser dito para as classes de educação financeira simplificadas, que utilizavam simples atalhos mentais.

Numa outra vertente, será feita uma análise de uma política que falha ao desconsiderar aspectos comportamentais. O Programa Nacional de Acesso ao Ensino Técnico - PRONATEC, que será o objeto da análise do próximo subitem, não obtém o êxito pretendido. Como será demonstrado, tal política não espera o erro de seus destinatários e, por conta disso, altos índices de evasão têm sido identificados - fato que pode, até mesmo, por em risco o futuro do programa. Também serão expostas maneiras de nítido cunho comportamental para se aprimorar tal política, a fim de contribuir para a redução da tributação cognitiva.

\subsection{O PRONATEC: uma abordagem comportamental}

O Programa Nacional de Acesso ao Ensino Técnico e Emprego - PRONATEC é um exemplo brasileiro de como a desconsideração dos fatores acima elencados pode reduzir drasticamente o impacto esperado de uma política.

O primeiro passo para a análise do Programa é a compreensão da sua razão de ser. Para isso, é extremamente oportuna a leitura da exposição de motivos da Lei 12.513 de 2011. Em diversos pontos desse documento é possível perceber a intenção de promover a inclusão social. É o que se percebe dos excertos a seguir:

O próprio crescimento econômico dos últimos anos aumenta a demanda por qualificação entre os trabalhadores brasileiros - cujo sucesso no mundo do trabalho depende cada vez mais de novas habilidades. É primordial atender esse público por meio de uma nova expansão da oferta de ensino profissional de qualidade. Em 2010, o número total de matrículas em cursos de Formação Inicial e Continuada foi de 2,4 milhões. Tal oferta, que inclui cursos pagos, é ainda tímida para atender a uma força de trabalho que passa dos 100 milhões.

Essa demanda é ainda mais acentuada entre os brasileiros de menor renda. Segundo dados do Cadastro Geral de Empregados e Desempregados - CAGED, mais de 40\% dos beneficiários reincidentes do seguro desemprego não chegaram a cursar o ensino médio. Já dados do Cadastro Único do Ministério do Desenvolvimento Social e Combate à Fome indicam que mais de $52 \%$ dos membros das quase 13 milhões de famílias beneficiadas pelo Programa Bolsa Família têm quatro anos ou menos de estudo formal. Diante dessa realidade, capacitar é incluir.

Este Governo, ciente de seu papel, reconheceu a necessidade de enfrentamento do problema, anunciando como uma das primeiras medidas a serem adotadas a criação de um amplo programa de acesso à formação profissional. O PRONATEC nasce como estratégia não só para resolver a questão 
dos gargalos de mão-de-obra, mas também como instrumento de melhoria da qualidade da educação, especialmente para os estudantes do ensino médio, bem como de inclusão social. ${ }^{133}$

Também pela letra da lei é possível constatar a intenção de se criar um mecanismo de inclusão social que, em última análise, busca reduzir as desigualdades. É o que se infere, por exemplo, dos seus dois primeiros artigos, in verbis:

Art. $1^{\circ}$ É instituído o Programa Nacional de Acesso ao Ensino Técnico e Emprego (Pronatec), a ser executado pela União, com a finalidade de ampliar a oferta de educação profissional e tecnológica, por meio de programas, projetos e ações de assistência técnica e financeira.

Parágrafo único. São objetivos do Pronatec:

I - expandir, interiorizar e democratizar a oferta de cursos de educação profissional técnica de nível médio presencial e a distância e de cursos e programas de formação inicial e continuada ou qualificação profissional;

II - fomentar e apoiar a expansão da rede física de atendimento da educação profissional e tecnológica;

III - contribuir para a melhoria da qualidade do ensino médio público, por meio da articulação com a educação profissional;

IV - ampliar as oportunidades educacionais dos trabalhadores, por meio do incremento da formação e qualificação profissional;

V - estimular a difusão de recursos pedagógicos para apoiar a oferta de cursos de educação profissional e tecnológica.

VI - estimular a articulação entre a política de educação profissional e tecnológica e as políticas de geração de trabalho, emprego e renda. (Incluído pela Lei no 12.816 , de 2013).

Art. $2^{\circ} \mathrm{O}$ Pronatec atenderá prioritariamente:

I - estudantes do ensino médio da rede pública, inclusive da educação de jovens e adultos;

II - trabalhadores;

III - beneficiários dos programas federais de transferência de renda; e

IV - estudante que tenha cursado o ensino médio completo em escola da rede pública ou em instituições privadas na condição de bolsista integral, nos termos do regulamento.

$\int 1^{\circ}$ Entre os trabalhadores a que se refere o inciso II, incluem-se os agricultores familiares, silvicultores, aquicultores, extrativistas e pescadores.

$\int 2^{\circ}$ Será estimulada a participação das pessoas com deficiência nas ações de educação profissional e tecnológica desenvolvidas no âmbito do Pronatec, observadas as condições de acessibilidade e participação plena no ambiente educacional, tais como adequação de equipamentos, de materiais pedagógicos, de currículos e de estrutura física.

$\int 3^{\circ}$ As ações desenvolvidas no âmbito do Pronatec contemplarão a participação de povos indígenas, comunidades quilombolas e adolescentes e jovens em cumprimento de medidas socioeducativas.

$\int 4^{\circ}$ Será estimulada a participação de mulheres responsáveis pela unidade familiar beneficiárias de programas federais de transferência de renda, nos cursos oferecidos por intermédio da Bolsa-Formação. (Incluído pela Lei no 12.816, de 2013) (134 $^{13}$

Ainda que o PRONATEC não seja política exclusiva para pessoas de baixa renda, trata-se de política cujos principais destinatários são indivíduos mais pobres. $\mathrm{O}$ art. $2^{\circ}$, acima citado, elucida que o público-alvo do programa é, prioritariamente dentre outras pessoas, aquelas ligadas a situações de pobreza, como no caso

133 BRASIL. Exposição de motivos interministerial no 19, de 28 de abril de 2011. Disponível em: <http://www.planalto.gov.br/ccivil_03/projetos/expmotiv/emi/2011/ 19-mec $\% 20 \mathrm{mte} \% 20 \mathrm{mf} \% 20 \mathrm{mp} \% 20 \mathrm{mds.htm}>$.

134 BRASIL. Lei no 12.513, de 26 de outubro de 2011. Brasília, Disponível em: <http://www.planalto.gov.br/ccivil_03/_ato20112014/2011/lei/112513.htm>. 
de beneficiários de programas federais de transferência de renda. Evidente, pois, tratar-se de política que, ao menos em parte, tem como destinatários as pessoas mais pobres. Logo, os efeitos perniciosos da tributação cognitiva, já expostos durante todo o trabalho, deveriam ser considerados desde a formulação da política, à época da elaboração da arquitetura de escolhas.

Um traço marcante da política, relacionado com a sua aplicação propriamente dita, diz respeito aos níveis de evasão notoriamente altos ${ }^{135}$. A Controladoria-Geral da União procedeu à auditoria do PRONATEC em 2013, tendo o relatório fruto da análise ${ }^{136}$ detectado falhas de controle interno que inviabilizavam a aferição precisa dos níveis de evasão do programa; contudo, índices não-oficiais apontam uma taxa média de abandono em torno de $50 \%{ }^{137} 138$.

Além das questões institucionais que perpassam qualquer análise de política pública, é possível verificar que a arquitetura de escolhas criada pelo PRONATEC desconsiderava que erros humanos são frequentes e que o autocontrole é limitado. Os altos índices de evasão do programa podem, muito bem, ser explicados por conta da desconsideração de problemas de cunho comportamental. Como a política tem como destinatários, principalmente, indivíduos de baixa renda, é evidente que, desde a elaboração de suas regras, deveria existir uma preocupação com os efeitos da tributação cognitiva.

O formulador de sua arquitetura de escolhas, nessas circunstâncias, deveria, desde o início, ter criado mecanismos que buscassem reduzir a evasão dos alunos e, além disso, incentivar a frequência. E, nesses pontos, as lições comportamentais aqui expostas são de extrema valia. Uma política que busca incentivar a formação e a especialização de trabalhadores, muitas vezes de baixa renda, deve esperar o erro e, no mínimo, considerar os possíveis riscos de evasão.

Isso porque, em se tratando de indivíduos em situação de pobreza, o presente trabalho demonstrou dados relacionados a maiores dificuldades de autocontrole, descontos intertemporais mais intensos e uma menor aversão ao risco. Há custos de oportunidade muito mais salientes para pessoas mais pobres, em comparação com as pessoas que ocupam os estratos superiores da sociedade. Com recursos escassos, a sua alocação envolve trade-offs mais intensos, entre bens de importância vital. Daí os maiores custos cognitivos e a maior recorrência de comportamentos enviesados em pessoas mais pobres. Em outras palavras, por essas razões, incide uma maior tributação cognitiva sobre as pessoas mais pobres.

Especificamente no que diz respeito à presença e à frequência em um curso profissionalizante, deve-se levar em conta os inúmeros trade-offs envolvidos para a realização dessa conduta. Não é uma decisão simples e as falhas de comportamento - no caso, os altos índices de evasão - não devem servir para condenar os destinatários do programa, como se a sua conduta fosse moralmente reprovável.

Permanecer em um programa de profissionalização é penoso, em última análise, porquanto significa renunciar tempo presente em benefício de condições futuras intangíveis. Em outros termos, enquanto o sujeito se profissionaliza, os resultados atuais de frequentar o curso podem não ser percebidos. Trata-se de um típico caso de decisão intertemporal. Como visto, as pessoas mais pobres tendem a descontar o futuro em maiores proporções, se comparadas com indivíduos mais ricos. Dificulta mais a questão que, enquanto os resultados intangíveis do curso profissionalizante não chegam, inúmeras necessidades mais prementes do

135 Vide:

http://www.valor.com.br/brasil/5129392/pronatec-teve-efeitos-limitados-e-evasao-alta-aponta-avaliacao;

http://g1.globo.com/educacao/noticia/2015/08/mec-fixa-novas-regras-para-repasse-integral-do-pronatec.html;

https://www.bbc.com/portuguese/noticias/2014/09/140901_evasao_pronatec_eleicoes_salasocial_ru;

136 CONTROLADORIA-GERAL DA UNIÃO.Relatório de auditoria anual de contas:relatório nº: 201406282. Brasília: CGU, 2014. Disponível em: <https://auditoria.cgu.gov.br/download/8990.pdf>.

137 VALOR ECONÔMICO.Programa de ensino técnico tem evasão de 19\%. Disponível em: <http://www.valor.com.br/brasil/3270550/programa-de-ensino-tecnico-tem-evasao-de-19>.

138 INSTITUTO DE PESQUISA ECONÔMICA APLICACDA (Ed.).PRONATEC: múltiplos arranjos e ações para ampliar o acesso à educação profissional.Brasília: IPEA, 2014. 63 p. Disponível em: <http://www.en.ipea.gov.br/agencia/images/stories/ PDFs/TDs/td_1919.pdf>. 
presente clamam pela atenção do sujeito, o que o leva, muitas vezes, a desistir do curso.

Imagine ter que conciliar o estudo profissionalizante com várias horas de trabalho, muitas vezes extremamente desgastantes; com o cuidado com a família, por exemplo, para encontrar um local para os filhos ficarem enquanto o pai se profissionaliza e trabalha; com o transporte para todos esses locais, que pode durar muitas horas, especialmente se o sujeito residir em regiões mais periféricas. Todo esse cenário pode levar o sujeito a desistir do seu curso profissionalizante, que poderia, em um futuro, melhorar a sua inserção no mercado de trabalho.

A situação acima descrita exemplifica de maneira clara os inúmeros e complexos trade-offs aos quais as pessoas mais pobres estão submetidas. A tomada de decisão, então, é consideravelmente mais custosa, o que parece levar mais rapidamente ao esgotamento do ego. Como exposto neste trabalho, tal processo mental prejudica o resultado das decisões - o que ajuda a explicar a incidência de uma maior tributação cognitiva sobre esses indivíduos. É possível supor, desta forma, que também o esgotamento do ego contribui para tornar mais difícil a decisão de permanecer vinculado ao PRONATEC ${ }^{139}$.

Corroboram essas afirmações estudos que apontam como causas para a evasão fatores ligados ao cuidado com a família e à dificuldade de conciliar os estudos com o trabalho ${ }^{140}$. Em um desses estudos, Medina ${ }^{141}$ aponta:

No caso do PRONATEC/OSM identificaram-se cinco problemas relacionados com o público-alvo.

O primeiro deles é a falta de disponibilidade do público para participar. As entrevistas feitas revelaram que a carga horária, as restrições familiares, as questões de saúde e busca de por fonte de renda dificultaram a assiduidade dos alunos. Um segundo problema identificado foi a questão das restrições familiares e de saúde. Encontraram-se casos nos quais as mulheres com filhos pequenos não tinham onde deixá-los ou mulheres que não podem frequentar os cursos porque o marido não permite. Os problemas de saúde do aluno ou de pessoa da família também figuraram como impeditivos importantes.

Outra restrição importante que tem o público-alvo é que a maioria está mais preocupada em conseguir dinheiro que em realizar um curso de qualificação profissional. As difíceis condições econômicas dos beneficiários os obrigam a realizarem atividades informais para subsistência, o que a sua vez impede que os alunos frequentem as aulas. Relacionado a este problema, as entrevistas evidenciaram que uma grande parcela do público-alvo não consegue dimensionar o potencial transformador do curso de qualificação antes de vivenciá-lo. Este problema obedece à falta de interesse intrínseca (sic) que impacta negativamente na adesão aos cursos de qualificação profissional.

Finalmente, a situação de vulnerabilidade destas pessoas é muito complexa. São pessoas carentes de serviços públicos básicos como saúde, saneamento básico e moradia adequada. Muitas delas têm problemas intrafamiliares e são vitimas de violência e marginalização social. Isso tudo em seu conjunto incrementa potencialmente os índices de evasão aos cursos de qualificação profissional.

O trecho citado demonstra, de maneira contundente, como os problemas de evasão do PRONATEC se

139 Necessário frisar que a possível correlação exposta deve ser entendida como uma hipótese a ser testada, subsidiando, eventualmente, conclusões mais significativas.

140 Vide: SANTOS, Talitha Araújo; ZAMBONI, Viviane de Paula Gouveia; OLIVEIRA, Maria Rita Neto Sales.Evasão e permanencia na educação profissional de jovens e adultos nos programas educacionais PROEJA e PRONATEC.In: SIMPOSIO INTERNACIONAL SITRE - TRABALHO, RELAÇÕES DE TRABALHO, EDUCAÇÃO E IDENTIDADE, 6. Disponível em: < http://www.sitre. cefetmg.br/arquivos/Anais/GT-01/sitreGT01p424_-_EVASxO_E_PERMANxNCIA_NA_EDUCAxO_PROFISSIONAL_ DE_JOVENS_E_ADULTOS_NOS_PROGRAMAS_EDUCACIONAIS_PROEJA_E_PRONATEC.pdf>.; e MEDINA, Maria Angélica Lozano. Causas de evasão em programas de qualificação profissional: análise dos casos de osasco e bogotá. 2012. Artigo (Mestrado) - Mestrado profissional em gestão e políticas públicas, Fundação Getúlio Vargas, São Paulo, 2012. Disponível em: <https:// bibliotecadigital.fgv.br/dspace/bitstream/handle/10438/10040/21.08.12\%20MPGPP\%20ARTIGO\%20INDIVIDUAL \%20-\%20 LOZANO $\% 20 \% 281 \% 29$.pdf? sequence $=3$ \&isAllowed $=\mathrm{y}>$.

141 MEDINA, Maria Angélica Lozano. Causas de evasão em programas de qualificação profissional: análise dos casos de osasco e bogotá. 2012. Artigo (Mestrado) - Mestrado profissional em gestão e políticas públicas, Fundação Getúlio Vargas, São Paulo, 2012. Disponível em: <https://bibliotecadigital.fgv.br/dspace/bitstream/handle/10438/10040/21.08.12\%20MPGPP\%20ARTIGO \%20 INDIVIDUAL $\% 20-\% 20$ LOZANO $\% 20 \% 281 \% 29$.pdf? sequence=3\&isAllowed $=\mathrm{y}>$. 
relacionam com as questões aqui levantadas da tributação cognitiva. A decisão de continuar no curso - i. e., não evadir - encontra-se umbilicalmente ligada à situação de pobreza, que prejudica e torna mais difícil o ato de decidir. Nesse caso, em termos claros, não privilegiar o presente não realizando um desconto intertemporal tão intenso é uma decisão extremamente custosa.

Isso se agrava se considerarmos as limitações de capacidade mental (mental bandwidth) provocadas pelos trade-offs mais intensos aos quais as pessoas em situação de pobreza estão submetidas: face à situação de ter que escolher entre estar presente em uma aula ou praticar a atividade que lhe assegure subsistência no presente, é esperado que o aluno se torne infrequente. Cria-se, em sequência, um ciclo vicioso, na medida em que a falta de hoje, prejudica o aprendizado de amanhã - e, pelo caráter cíclico e incremental da situação, ao fim e ao cabo provoca-se a evasão.

Shafir e Mullainathan ${ }^{142}$, ao analisar o contexto de programas de treinamento, como o PRONATEC, descrevem o problema com precisão:

Considere os programas de treinamento, nos quais o absenteísmo é comum e os índices de evasão são altos. O que acontece quando, sobrecarregado e esgotado, um cliente perde uma aula? O que acontece quando a sua mente vaguear durante a aula? A próxima aula se torna muito mais difícil. Perder uma ou duas aulas a mais e desistir se torna o resultado natural, talvez até mesmo a melhor opção, tendo em vista que ele realmente não mais entende muito do que está sendo discutido na aula. Um currículo rígido - cada classe construída sobre a anterior - não é um ajuste que perdoa estudantes cuja capacidade mental está sobrecarregada. [...] O design desses programas presume que se as pessoas estiverem suficientemente motivadas, elas não cometerão erros. Aqueles que não conseguem se dar o trabalho de chegar à aula pontualmente, continua o argumento implícito, não devem importar: eles não "merecem" o treinamento.

Mas a psicologia da escassez prevê que erros como esse serão todos muito comuns, talvez até mesmo inevitáveis, independentemente do quão motivada esteja a pessoa. Imagine que você chega em casa após um dia no trabalho, preocupado sobre como você conseguirá dinheiro para pagar o aluguel desse mês, todas as contas e a festa de aniversário de sua filha. Você não tem dormido bem. Há algumas semanas, você se inscreveu para um programa de treinamento em habilidades informáticas que um dia poderia ajudá-lo a conseguir um emprego melhor. Mas essa noite os benefícios desse treinamento são abstratos e distantes. Você está exausto e sobrecarregado por coisas mais próximas, e você sabe que, mesmo se você for à aula, você não absorverá nada. Agora avance algumas semanas. Nesse momento, você perde outra aula. E quando você vai, você entende menos do que antes. Eventualmente, você decide que não aguenta toda essa carga agora; você desistirá e fará a inscrição em um outro momento, quando a sua vida financeira estiver em melhor condições. O programa que você tentou não foi projetado para tolerar faltas. Ele potencializou os seus erros, que eram previsíveis e essencialmente empurrou-o para fora.

Por isso, o arquiteto de escolhas deve pensar em todos esses fatores e tentar, ao elaborar a arquitetura de escolhas, incentivar a permanência nos cursos, por exemplo, por meio de Nudges. Frise-se que políticas mais paternalistas, com maior grau de intervenção estatal, produziriam algum efeito diante do problema - haja vista as inúmeras intervenções estruturais já catalogadas que versam sobre o tema.

Extrapola os objetivos deste trabalho esgotar todas as abordagens políticas possíveis para aperfeiçoar o PRONATEC. Pretende-se, aqui, apontar possíveis intervenções - principalmente de cunho comportamental - para diminuir os índices de evasão do programa. Por óbvio, para aplicá-las, é necessário, antes de mais nada, avaliar empiricamente a sua efetividade. Por isso, os exemplos trazidos são, principalmente, propostas de agendas de pesquisa que unem elementos comportamentais relacionados com a diminuição dos efeitos psicologicamente adversos da pobreza - isto é, da tributação cognitiva.

De início, um exemplo de nudge que poderia ser implementado sem maiores custos se baseia na ideia de lembretes, que poderiam ser enviados tanto eletronicamente, quanto por meio de correspondências físicas.

142 MULLAINATHAN, Sendhil; SHAFIR, Eldar. Scarcity: why having too little means so much. Nova Iorque: Time Books, Henry Holt \& Company Llc, 2014. p. 249-250. Tradução nossa. 
Em tais mensagens, os benefícios de cursos profissionalizantes poderiam ser enfatizados, em conjunto com a valorização de fatores como a frequência do estudante para o seu bom desempenho. Vale ressaltar que, conforme será demonstrado a seguir, a política de lembretes teve êxito no Reino Unido para diminuir os índices de evasão e de ausências em cursos de educação para adultos.

Os detalhes de tais mensagens variam conforme a própria criatividade do gestor, mas alguns elementos basilares podem ser indicados com base nas ciências comportamentais.

Como os resultados futuros dos cursos são intangíveis, um primeiro aspecto a ser identificado pelo arquiteto de escolhas diz respeito à tentativa de dar maior grau de concretude a esses resultados. Isso poderia acontecer por meio de dados, expostos de maneira simples e chamativa, que enfatizem o resultado positivo que os cursos proporcionam para aqueles que finalizam os seus estudos. Tais indicativos podem girar em torno de elementos como o percentual de inserção no mercado de trabalho, os ganhos de renda e, até mesmo, elementos que apontem para benefícios em termos de poder de compra ou de felicidade. Evidentemente que, para a elaboração da mensagem, o acompanhamento dos resultados do próprio programa deve ser realizado. Não é esta questão técnica, contudo, limitadora de sugestões.

Um outro fator que pode ser considerado, na elaboração dessa mensagem, relaciona-se com as normas sociais. Como já ressaltado, muitos nudges funcionam com base em dar ênfase ao comportamento de uma coletividade. Nessa perspectiva, é possível, por exemplo, destacar, na mensagem, que um percentual x de indivíduos permanece vinculado ao curso. Ainda que se possa afirmar que, caso esse percentual seja baixo, o nudge poderia ter efeitos adversos, as normas sociais podem ser utilizadas ainda de outra maneira. Enfatizar os custos sociais que a conduta evasiva provoca e os benefícios que a conclusão do curso pode gerar para a sociedade também pode ter efeitos positivos.

Por fim, complementando a mensagem proposta, é possível dar feedbacks visuais aos estudantes, por exemplo, acrescentando à mensagem um "emoticon" triste associado à evasão - ou à falta de frequência adotada. Essa estratégia foi utilizada com sucesso em San Marco, na Califórnia, para a redução do consumo de energia ${ }^{143}$. Analogamente, é possível atribuir "emoticons" felizes em mensagens para os indivíduos que têm tido um bom comportamento, de forma a dar um feedback visual positivo à sua conduta. Podem contribuir, para esse contexto, estratégias ligadas à gamificação (gamification), com a atribuição de metas ligadas ao bom desempenho no curso. Cumpridas as metas, feedbacks automáticos seriam enviados para os estudantes, de forma a incentivar que continuem mantendo o bom comportamento. Por exemplo, é possível estabelecer que, após 15 dias seguidos de comparecimento à aula, o sujeito ganhe uma "conquista" que ficaria vinculada à sua conta virtual na plataforma do curso.

A boa aplicação deste nudge envolve o monitoramento dos índices de frequência de cada aluno, cuja diminuição, em geral, pode indicar uma possível desistência próxima. Com esse controle, é possível que, além das mensagens, sejam feitas reuniões com os alunos mais ausentes, nas quais esses valores poderiam ser melhor enfatizados e, ademais, nas quais estratégias individuais possam ser pensadas, conforme as particularidades de cada estudante.

A composição do nudge aqui proposto pode ser melhor identificada nas figuras a seguir:

143 THALER, Richard H.; SUNSTEIN, Cass R.Nudge:improving decisions about health, wealth and happiness. Londres: Penguin Books, 2009. p. 69-70. 
Figura 2

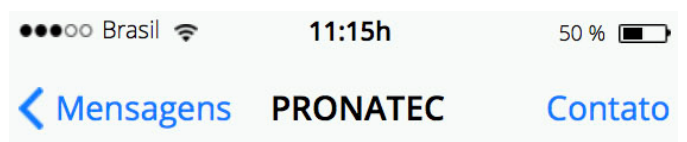

Terça-feira, 22 de maio 20:30h

Fulano, lembre-se de seus

objetivos! Compareça ao seu

curso do PRONATEC!

Segunda-feira, 28 de maio 13:00h

A conclusão do seu curso

técnico oferecido pelo

PRONATEC aumenta as em

$25 \%$ as suas chances de

conseguir um emprego e

aproxima você do sonho da

casa própria em três anos

(estimativa média para sua

localidade e curso).

Compareça ao seu curso,

Fulano!

Sexta-feira, 01 de junho 14:00h

Nas últimas duas semanas

você teve frequência de $20 \%$.

Cuidado :: : :

O. Digite aqui a mensagem.

Fonte: Do autor.144

144 Os dados indicados na figura são meramente ilustrativos. 
Figura 3

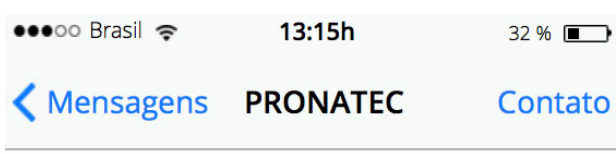

Terça-feira, 05 de junho 15:45h

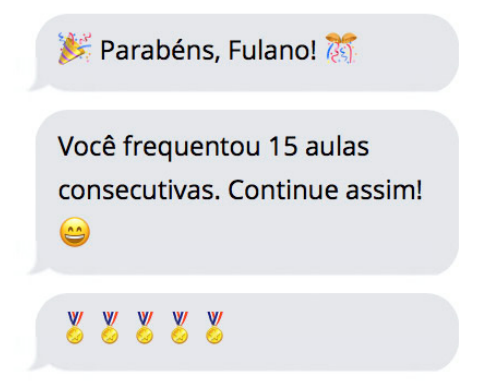

(O) Digite aqui a mensagem. Enviar

Fonte: Do autor.

Nesse ponto, o seguinte alerta é fundamental: deve-se atentar para que o nudge proposto não contribua para reforçar a tributação cognitiva, potencialmente regressiva. Isso porque, sozinho, tal nudge pode ser incapaz de melhorar a situação e pode, ao revés, contribuir apenas para que as decisões dos destinatários da política se tornem mais difíceis. Cumulado com modificações estruturais, tais como a disponibilização de horários mais flexíveis e compatíveis com o trabalho, o nudge poderia potencializar os efeitos dessa política pública. Vale lembrar, aqui, a lição de Loewenstein e Chater ${ }^{145}$ :

[...] compreender muito dos problemas da sociedade e formular soluções de políticas envolverá híbridos entre a economia tradicional e a comportamental, em vez da aplicação pura de qualquer uma das duas. O crescimento da Economia Comportamental deve, portanto, ser visto como suplementar, em vez de substitutivo das análises econômicas e métodos políticos tradicionais. Políticas comportamentais efetivas, e especialmente políticas visando os problemas que colocam os desafios mais significativos para a geração atual, exigirão uma combinação fluída e flexível de insights de ambas as tradições.

Nessa linha de raciocínio, é possível pensar em uma alteração que, apesar de ter fundo nitidamente comportamental ${ }^{146}$, é de cunho mais estrutural, alterando de maneira mais intensa a própria maneira como os cursos do PRONATEC são imaginados.

Como já ressaltado, permanecer vinculado ao PRONATEC é uma decisão intertemporal complexa. Por conta disso, os destinatários da política - na maior parte das vezes, pessoas de baixa renda - têm dificuldades

145 LOEWENSTEIN, George; CHATER, Nick. Putting nudges in perspective. Behavioural Public Policy, [s.1.], v. 1, n. 01, p. 26-53, maio 2017. Cambridge University Press (CUP). Disponível em: <http://dx.doi.org/10.1017/bpp.2016.7>. p. 48. Tradução nossa.

146 Deve-se ter em mente que, em última análise, toda e qualquer política tem aspectos comportamentais. A compreensão do comportamento dos destinatários - ou, ao menos, uma ideia de como ele funciona - é aspecto fundamental tanto para o desenho da política, quanto para a sua posterior aplicação. 
de concluir os cursos e os índices de evasão são consideravelmente elevados. Especificamente quanto a esse problema, Shafir e Mullainathan ${ }^{147}$ oferecem uma intervenção positiva:

Mas não precisa ser dessa maneira. Em vez de insistir na ausência de erros ou para modificar o comportamento, pode-se redefinir o cockpit ${ }^{48}$. Currículos podem ser alterados, por exemplo, para existirem módulos, determinados a começar em diferentes épocas e a prosseguir em paralelo. Você perdeu uma aula e ficou para trás? Vá para a sessão paralela, que está uma ou duas semanas "atrás" dessa. Perca um módulo e você pode voltar aos trilhos na próxima rodada. Certamente, levará mais tempo para você finalizar, mas, ao menos, você chegará lá. Da maneira como é hoje, os programas de treinamento são criados sem que os erros sejam considerados, como se não fossem esperados ou tolerados erros por parte dos participantes. Mas os pobres - mesmo, ou talvez especialmente, quando desempregados - possuem muitas coisas a fazer. E muitas delas não são facilmente conciliáveis com ser um estudante. Faltar aulas em um programa de treinamento enquanto você convive com a escassez não é o mesmo que "matar" aula no colégio. Classes lineares que não podem ser perdidas podem funcionar bem para estudantes de tempo integral; elas não fazem sentido para os pobres malabaristas ${ }^{149}$.

A intervenção proposta por Mullainathan e Shafir é perfeitamente aplicável ao PRONATEC. Em vez de apostar em maneiras de ensino lineares e tradicionais, pode-se utilizar o ensino em módulos, como forma de minimizar os erros dos destinatários da política pública. Assim, se faltas são recorrentes e acabam por levar à desistência, o ensino em módulos pode ser uma forma de atenuar esses problemas. Uma atenção é necessária, contudo, para que tal prática não seja desvirtuada. O objetivo não é, de maneira alguma, perpetuar o período dos estudantes no curso. Por isso, um acompanhamento individual de cada estudante é primordial, cumulado com o nudge proposto acima. Dessa forma, ainda que os sujeitos gastem mais tempo para concluir a sua formação, terão resultados melhores que a mera desistência.

Em suma, o uso cumulado de ambas as estratégias, de forma a se utilizar o nudge elaborado acima, para enviar mensagens personalizadas para cada estudante, e a se adotar o ensino em módulos, é capaz de reduzir os efeitos perversos da tributação cognitiva e melhorar consideravelmente o PRONATEC. Com isso, seus resultados seriam potencializados. O exemplo do PRONATEC mostra como a falta de informação à época da elaboração de uma política pública pode trazer resultados adversos. Os altos índices de evasão contribuem para que os trabalhadores não se profissionalizem, o que dificulta o seu acesso ao mercado de trabalho. Evidentemente, há o reforço de sua própria situação de pobreza e de dependência do Estado. As propostas apresentadas, entretanto, mostram como a consideração de aspectos comportamentais, à época da criação da arquitetura de escolhas, pode aprimorar e sofisticar uma política pública e potencializar os seus resultados - além, é claro, de reduzir a tributação cognitiva.

Portanto, é impositivo que o arquiteto de escolhas, ao desenhar a sua política pública, esteja informado dos vieses comportamentais que estão presentes em todos os humanos, com as peculiaridades expostas da situação pobreza, e atento aos possíveis incentivos perniciosos que sua política pode gerar. Trata-se, pois, de uma abordagem essencial para que resultados positivos possam ser atingidos e contribuam efetivamente para a redução da tributação cognitiva.

147 MULLAINATHAN, Sendhil; SHAFIR, Eldar. Scarcity: why having too little means so much. Nova Iorque: Time Books, Henry Holt \& Company Llc, 2014. p. 250-251. Tradução nossa.

148 Trata-se de metáfora utilizada pelos autores para a arquitetura de escolhas. Num avião, a disposição de controles é feita de modo a minimizar o efeito de erros dos pilotos. Busca-se evitar que, por engano, duas alavancas sejam confundidas, o que poderia provocar um acidente. Analogamente, em uma política pública, não se deve esperar um comportamento perfeito dos destinatários. Deve-se, na verdade, estudar o comportamento humano de forma a, na formulação da arquitetura de escolhas, criar mecanismos que, esperando o erro, minimizem os seus efeitos.

149 A expressão é usada como uma metáfora para as muitas coisas com as quais os pobres têm que lidar. 


\section{Considerações finais}

Conforme demonstrado, a situação de pobreza, por si só, tem o condão de prejudicar as decisões econômicas. As pessoas que se encontram nessa condição, por conta dos trade-offs mais intensos impostos pelo fato dos excessivos custos de oportunidade inerentes à situação de escassez, passam por um processo exacerbado de esgotamento do ego, paralelamente à diminuição das funções cognitivas, ao direcionamento do foco atencional para a própria condição de escassez, ao aumento dos índices de stress e de afeto negativo. Demonstrou-se que, por conta de todos esses fatores, maiores descontos intertemporais e um comportamento mais avesso ao risco são constatados em populações mais pobres.

Utilizou-se, neste trabalho, a expressão figurada tributação cognitiva para representar esse fenômeno, na linha proposta por Mani $e t$ al ${ }^{150}$, tendo em vista que os maiores custos cognitivos que estão presentes nas decisões econômicas de pessoas mais pobres podem ser capazes de reforçar a própria condição de pobreza. Diante desse quadro, o gestor, à época de se formular a arquitetura de escolhas de uma política pública, portanto, deve estar ciente de todos esses resultados. Como ressaltado, os resultados de políticas públicas podem ser desastrosos se não se considera o modo como os seus destinatários se comportam. Isso, para além de saber se tratarem de Homo Sapiens e não de Homo Economicus, implica, também, em ter ciência dos vieses comportamentais mais recorrentes na situação de pobreza. Escolher é sempre custoso e sempre envolve custos de oportunidade. Na situação de maior escassez, isso se agrava e, como demonstrado, os custos cognitivos também são consideravelmente mais intensos.

O PRONATEC é um exemplo claro de política que desconsidera esses fatores e que não espera o erro das pessoas às quais ela se destina. Para melhorá-lo, pode-se criar um nudge, que consistiria em lembretes enviados por mensagem para os alunos, de forma a reforçar valores que são positivos para a diminuição dos índices de evasão. Tais fatores passam pelo uso de normas sociais, pela materialização dos resultados positivos do programa, pelo reforço do comprometimento prévio e por métodos de feedback instantâneos, que incluem estratégias de gamificação (gamification). Outra estratégia que pode ser adotada, na linha proposta por Shafir e Mullainathan ${ }^{151}$, é o ensino em módulo. Assim, é possível amenizar os efeitos de erros dos indivíduos, no caso, das faltas, e criar mais incentivos para que eles permaneçam frequentando as aulas.

Ao mesmo tempo, os casos dos lembretes voltados a diminuir a taxa de evasão e aumentar a frequência no ensino de matemática e inglês para adultos, no Reino Unido, e do ADOPEM, relacionado à educação financeira por meio de simples atalhos mentais, na República Dominicana, mostram a força que podem ter políticas bem informadas em relação ao comportamento humano.

As pessoas não possuem capacidade cognitiva para decidir tudo de maneira adequada. A formulação de políticas públicas deve ter ciência disso - e de como tal situação se intensifica na pobreza - para trabalharem em prol da "construção" dessa capacidade mental. Em outras palavras: deixar que as pessoas deliberem e escolham com maior atenção nas ocasiões que lhes são mais urgentes. A lição que pode ser concluída, por todas as informações trazidas nesse trabalho, é que há uma verdadeira tributação cognitiva imposta a pessoas mais pobres, por conta dos efeitos psicológicos adversos provocados pela própria escassez. Cabe ao gestor, portanto, ter ciência disso para diminuir o impacto de tais efeitos e evitar que os seus efeitos regressivos possam criar uma espécie de ciclo vicioso, com o autorreforço da pobreza.

150 MANI, A. et al. Poverty impedes cognitive function. Science, [s.l.], v. 341, n. 6149, p. 976-980, 29 ago. 2013. American Association for the Advancement of Science (AAAS). Disponível em: <http://dx.doi.org/10.1126/science.1238041>. p. 980.

151 MULLAINATHAN, Sendhil; SHAFIR, Eldar. Scarcity: why having too little means so much. Nova Iorque: Time Books, Henry Holt \& Company Llc, 2014. p. 250-251. 


\section{REFERÊNCIAS}

ARIELY, Dan.Positivamente irracional:os benefícios inesperados de desafiar a lógica em todos os aspectos de nossas vidas. Rio de Janeiro: Elsevier, 2010.

ARIELY, Dan.Previsivelmente Irracional.Rio de Janeiro: Elsevier, 2008.

ÁVILA, Flávia; BIANCHI, Ana Maria.Guia de economia comportamental e experimental.São Paulo: Economiacomportamental.org, 2015.

BAUMEISTER, Roy F. et al. Ego depletion: is the active self a limited resource?Journal of Personality and Social Psychology, [s.1.], v. 74, n. 5, p. 1252-1265, maio 1998.

BAUMEISTER, Roy F. et al. Free will in consumer behavior: Self-control, ego depletion, and choice.Journal of Consumer Psychology, [s.1.], v. 18, n. 1, p. 4-13, jan. 2008.

BAUMEISTER, Roy F. et al. Self-regulation and personality: how interventions increase regulatory success, and how depletion moderates the effects of traits on behavior.Journal of Personality, [s.l.], v. 74, n. 6, p. 17731802, dez. 2006.

BAUMEISTER, Roy F.; TIERNEY, John.Willpower:rediscovering the greatest human strength. [s.l.]: Penguin Books, 2012.

BERNOULLI, Daniel. Exposition of a new theory on the measurement of risk.Econometrica, [s.l.], v. 22, n. 1, p. 22-36, jan. 1954. Disponível em: < https://engineering.purdue.edu/ ipollak/ece302/FALL09/notes/ Bernoulli_1738.pdf>.

BRASIL. Exposição de motivos interministerial nº 19, de 28 de abril de 2011. Disponível em: < http:/ /www.planalto. gov.br/ccivil_03/projetos/expmotiv/emi/2011/ 19-mec\%20mte\%20mf\%20mp\%20mds.htm>.

BRASIL. Lei no 12.513, de 26 de outubro de 2011. Brasília, Disponível em: <http://www.planalto.gov.br/ccivil_03/_ato2011-2014/2011/lei/112513.htm>.

CONTROLADORIA-GERAL DA UNIÃO.Relatório de auditoria anual de contas:relatório nº: 201406282. Brasília: CGU, 2014. Disponível em: <https://auditoria.cgu.gov.br/download/8990.pdf>.

DANZINGER, Shai; LEVAV, Jonathan; AVNAIM-PESSO, Liora. Extraneous factors in judicial decisions. Proceedings of The National Academy of Sciences of the United States of America, Princeton, v. 108, n. 17, p. 68896892, 26 abr. 2011.

DE FAVERI, Dinorá Baldo.Impaciência nas escolhas intertemporais:uma abordagem comportamental. 2017. 227 f. Tese (Doutorado) - Curso de Programa de Pós-graduação em Economia, Universidade Federal de Santa Catarina, Florianópolis, 2017. Disponível em: <https://repositorio.ufsc.br/bitstream/ handle/123456789/183406/349814.pdf?sequence $=1>$.

DOHMEN, Thomas et al. Individual risk attitudes: measurement, determinants, and behavioral consequences.Journal of The European Economic Association, [s.1.], v. 9, n. 3, p. 522-550, 31 mar. 2011. Oxford University Press (OUP). Disponível em: <http://dx.doi.org/10.1111/j.1542-4774.2011.01015.x>.

DREXLER, Alejandro; FISCHER, Greg; SCHOAR, Antoinette. Keeping it simple: financial literacy and rules of thumb. American Economic Journal: Applied Economics, [s.1.], v. 6, n. 2, p. 1-31, abr. 2014. American Economic Association. Disponível em: <http://dx.doi.org/10.1257/app.6.2.1>.

FREDERICK, Shane; LOEWENSTEIN, George; O'DONOGHUE, Ted. Time discounting and time preference: a critical review.Journal of Economic Literature, [s.l.], v. 40, n. 2, p. 351-401, jun. 2002. American Economic Association. Disponível em: <http://dx.doi.org/10.1257/002205102320161311>.

GAILLIOT, Matthew T. et al. Self-control relies on glucose as a limited energy source: willpower is more 
than a metaphor.Journal of Personality and Social Psychology, [s.1.], v. 92, n. 2, p. 325-336, 2007. American Psychological Association (APA).

GAILLIOT, Matthew T.; BAUMEISTER, Roy F. The physiology of willpower: linking blood glucose to self-control.Personality and Social Psychology Review, [s.1.], v. 11, n. 4, p. 303-327, nov. 2007. SAGE Publications.

GICO JÚNIOR, Ivo Teixeira. Metodologia e epistemologia da análise econômica do direito.Economic Analysis of Law Review, Brasilia, v. 1, n. 1, p. 7-33, 11 jun. 2010. Semestral.

GUISO, Luigi; PAIELLA, Monica. Risk aversion, wealth, and background risk. Journal of The European Economic Association, [s.1.], v. 6, n. 6, p. 1109-1150, dez. 2008. Oxford University Press (OUP). Disponível em: <http://dx.doi.org/10.1162/jeea.2008.6.6.1109>.

HAMILTON, Ryan; HONG, Jiewen; CHERNEV, Alexander. Perceptual focus effects in choice.Journal of Consumer Research, [s.1.], v. 34, n. 2, p. 187-199, ago. 2007. Oxford University Press (OUP).

HAUSHOFER, J.; FEHR, E. On the psychology of poverty. Science, [s.1.], v. 344, n. 6186, p.862-867, 22 maio 2014. American Association for the Advancement of Science (AAAS). Disponível em: < http:// dx.doi.org/10.1126/science.1232491>.

INSTITUTO DE PESQUISA ECONÔMICA APLICACDA (Ed.).PRONATEC: múltiplos arranjos e ações para ampliar o acesso à educação profissional.Brasília: IPEA, 2014. 63 p. Disponível em: < http:// www.en.ipea.gov.br/agencia/images/stories/PDFs/TDs/td_1919.pdf>.

KAHNEMAN, Daniel.Rápido e devagar:duas formas de pensar. Rio de Janeiro: Objetiva, 2012.

KAHNEMAN, Daniel; TVERSKY, Amos. Prospect theory: an analysis of decision under risk.Econometrica, [s.1.], v. 47, n. 2, p. 263-292, mar. 1979. Disponível em: < http://people.hss.caltech.edu/ camerer/Ec101/ ProspectTheory.pdf $>$.

LAWRANCE, Emily C. Poverty and the rate of time preference: evidence from panel data.Journal of Political Economy, [s.1.], v. 99, n. 1, p. 54-77, fev. 1991. University of Chicago Press. Disponível em: < http://dx.doi. org/10.1086/261740>.

LOEWENSTEIN, George; CHATER, Nick. Putting nudges in perspective. Behavioural Public Policy, [s.l.], v. 1, n. 01, p. 26-53, maio 2017. Cambridge University Press (CUP). Disponível em: <http://dx.doi. org/10.1017/bpp.2016.7>.

MANI, A. et al. Poverty impedes cognitive function. Science, [s.l.], v. 341, n. 6149, p. 976-980, 29 ago. 2013. American Association for the Advancement of Science (AAAS). Disponível em: <http://dx.doi. org/10.1126/science.1238041>.

MANKIW, N. Gregory. Introducão à economia. 3. ed. São Paulo: Cengage Learning, 2009.

MEDINA, Maria Angélica Lozano. Causas de evasão em programas de qualificação profissional: análise dos casos de osasco e bogotá. 2012. Artigo (Mestrado) - Mestrado profissional em gestão e políticas públicas, Fundação Getúlio Vargas, São Paulo, 2012. Disponível em: <https://bibliotecadigital.fgv.br/dspace/bitstream/ handle/10438/10040/21.08.12\%20MPGPP\%20ARTIGO\%20INDIVIDUAL\%20-\%20LOZANO $\% 20$ $\% 281 \% 29$.pdf? sequence $=3 \&$ is Allowed $=\mathrm{y}>$.

MULLAINATHAN, Sendhil; SHAFIR, Eldar. Scarcity: why having too little means so much. Nova Iorque: Time Books, Henry Holt \& Company Llc, 2014.

MURAMATSU, Roberta; FONSECA, Patrícia. Economia e psicologia na explicação da escolha intertemporal.Revista de Economia Mackenz̨ie, São Paulo, v. 6, n. 6, p. 87-112. 2008. Disponível em: < http://editorarevistas.mackenzie.br/index.php/rem/article/view/810>.

OECD.Behavioural insights andpublic policy:lessons from around the world, OECD Publishing, Paris,Disponível 
em: <http://dx.doi.org/10.1787/9789264270480-en>.

PENDER, John L. Discount rates and credit markets: theory and evidence from rural india.Journal Of Development Economics, [s.1.], v. 50, n. 2, p. 257-296, ago. 1996. Elsevier BV. Disponível em: < http://dx.doi. org/10.1016/s0304-3878(96)00400-2>.

RICK, Scott; LOEWENSTEIN, George. Intangibilidade na escolha intertemporal. In: ÁVILA, Flávia; BIANCHI, Ana Maria.Guia de economia comportamental e experimental.São Paulo: Economiacomportamental. org, 2015. p. 76-97.

SAEZ, Emmanuel; ZUCMAN, Gabriel. Wealth inequality in the united states since 1913: evidence from capitalized income tax data.National Bureau Of Economic Research, Cambridge, Ma, p.1-46, out. 2014. National Bureau of Economic Research . Disponível em: <http://dx.doi.org/10.3386/w20625>.

SAMSON, Alain. Introdução à economia comportamental e experimental. In: ÁVILA, Flávia; BIANCHI, Ana Maria.Guia de Economia Comportamental e Experimental.São Paulo: Economiacomportamental.org, 2015. p. 25-59.

SAMUELSON, Paul A. A note on measurement of utility.The Review of Economic Studies, [s.l], v. 4, n. 2, p. 155-161, fev. 1937. Publicado pela Oxford University Press. Disponível em: <http://www.jstor.org/stable/2967612>.

SANTOS, Talitha Araújo; ZAMBONI, Viviane de Paula Gouveia; OLIVEIRA, Maria Rita Neto Sales. Evasão e permanencia na educação profissional de jovens e adultos nos programas educacionais PROEJA e PRONATEC.In: SIMPOSIO INTERNACIONAL SITRE - TRABALHO, RELAÇÕES DE TRABALHO, EDUCAÇÃO E IDENTIDADE, 6. Disponível em: <http://www.sitre.cefetmg.br/arquivos/Anais/ GT-01/sitreGT01p424_-_EVASxO_E_PERMANxNCIA_NA_EDUCAxO_PROFISSIONAL_DE_ JOVENS_E_ADULTOS_NOS_PROGRAMAS_EDUCACIONAIS_PROEJA_E_PRONATEC.pdf $>$.

SHAH, A. K.; MULLAINATHAN, S.; SHAFIR, E. Some consequences of having too little. Science, [s.l.], v. 338, n. 6107, p. 682-685, nov. 2012. American Association for the Advancement of Science (AAAS). Disponível em: < http://dx.doi.org/10.1126/science.1222426>.

SMITH, Adam.The theory of moral sentiments.São Paulo: Metalibri, 2006. Disponível em: < https://www.ibiblio.org/ml/libri/s/SmithA_MoralSentiments_p.pdf>.

SPEARS, Dean. Decision costs and price sensitivity: field experimental evidence from India.Journal Of Economic Behavior \& Organization, [s.1.], v. 97, p. 169-184, jan. 2014. Elsevier BV. Disponível em: < http://dx.doi. org/10.1016/j.jebo.2013.06.012>.

SPEARS, Dean. Economic decision-making in poverty depletes behavioral control.The B.e. Journal of Economic Analysis \& Policy, [s.l], v. 11, n. 1, p. 1-42, 2011. Disponível em: < http://lisagennetian.org/files/92920599. $\mathrm{pdf}>$.

STARMER, Chris. Entendendo preferências: o que podemos aprender com a economia comportamental?. In: ÁVILA, Flávia; BIANCHI, Ana Maria.Guia de Economia Comportamental e Experimental.São Paulo: Economiacomportamental.org, 2015. p. 60-75.

SUNSTEIN, Cass R. Choosing not to choose: understanding the value of choice. New York: Oxford University Press, 2015.

SUNSTEIN, Cass R. Nudging: um guia bem breve. In: ÁVILA, Flávia; BIANCHI, Ana Maria. Guia de Economia Comportmental e Experimental. São Paulo: Economiacomportamental.org, 2015. p. 109-114.

TANAKA, Tomomi; CAMERER, Colin F; NGUYEN, Quang. Risk and time preferences: linking experimental and household survey data from Vietnam. American Economic Review, [s.l.], v. 100, n. 1, p. 557-571, mar. 2010. American Economic Association. Disponível em: <http://dx.doi.org/10.1257/aer.100.1.557>. 
TIERNEY, John.Do you suffer from decision fatigue?. Disponível em: <https://www.nytimes.com/2011/08/21/ magazine/do-you-suffer-from-decision-fatigue.html>.

THALER, Richard H.; BENARTZI, Shlomo. Save more tomorrow ${ }^{\text {TM}}$ : using behavioral economics to increase employee saving. Journal Of Political Economy, [s.l.], v. 112, n. 1, p. 164-187, fev. 2004. University of Chicago Press. Disponível em: <http://dx.doi.org/10.1086/380085>.

THALER, Richard H.; SUNSTEIN, Cass R.Nudge.improving decisions about health, wealth and happiness. Londres: Penguin Books, 2009.

THALER, Richard.Mishehaving:the making of behavioral economics. Nova Iorque: W. W. Norton, 2016.

WALLACE, Harry M.; BAUMEISTER, Roy F. The effects of success versus failure feedback on further self-control.Self and Identity, [s.l.], v. 1, n. 1, p. 35-41, jan. 2002.

VALOR ECONÔMICO.Programa de ensino técnico tem evasão de 19\%. Disponível em: < http:/ /www.valor.com. $\mathrm{br} /$ brasil/3270550/programa-de-ensino-tecnico-tem-evasao-de-19>.

VOHS, Kathleend.; FABER, RonaldJ. Spent resources: self-regulatory resource availability affects impulse buying.Journal of Consumer Research, [s.l.], v. 33, n. 4, p. 537-547, mar. 2007.

VOHS, Kathleen D.; HEATHERTON, Todd F. Self-regulatory failure: a resource-depletion approach.Psychological Science, [s.l.], v. 11, n. 3, p. 249-254, maio 2000.

VON NEUMANN, John; MORGENSTERN, Orkas. Theory of games and economic behavior:Princeton: Princeton University Press, 1953.

YESUF, Mahmud; BLUFFSTONE, Randall. Wealth and time preference in rural ethiopia.Environment For Development, [s.1.], v. 16, n. 08, p. 1-18, jun. 2008. Disponível em: <http://www.rff.org/files/sharepoint/ WorkImages/Download/EfD-DP-08-16.pdf>. 
Para publicar na revista Brasileira de Políticas Públicas, acesse o endereço eletrônico www.rbpp.uniceub.br

Observe as normas de publicação, para facilitar e agilizar o trabalho de edição. 